\title{
Lanthanide compounds as catalysts for the one-step synthesis of vinyl chloride from ethylene
}

Matthias Scharfe,${ }^{\dagger}$ Pedro A. Lira-Parada, ${ }^{\dagger}$ Amol P. Amrute, Sharon Mitchell, and Javier PérezRamírez ${ }^{\star}$

Institute for Chemical and Bioengineering, Department of Chemistry and Applied Biosciences, ETH Zurich, Vladimir-Prelog-Weg 1, 8093 Zurich, Switzerland.

${ }^{\dagger}$ Equal contribution | ${ }^{*}$ Corresponding author. E-mail: jpr@chem.ethz.ch. 


\section{Abstract}

The industrial manufacture of vinyl chloride relies on a two-step process involving $\mathrm{CuCl}_{2}$-catalyzed ethylene oxychlorination to ethylene dichloride followed by thermal cracking of the latter to vinyl chloride. This work evaluates a wide range of commercial and self-prepared lanthanide ( $\mathrm{La}, \mathrm{Ce}, \mathrm{Pr}$, $\mathrm{Nd}, \mathrm{Sm}, \mathrm{Eu}, \mathrm{Gd}, \mathrm{Tb}, \mathrm{Dy}, \mathrm{Ho}$, and Er) compounds for the one-step production of vinyl chloride from ethylene in a fixed-bed reactor at $623-773 \mathrm{~K}$ and 1 bar using feed ratios of $\mathrm{C}_{2} \mathrm{H}_{4}: \mathrm{HCl}: \mathrm{O}_{2}: \mathrm{Ar}: \mathrm{He}=3-$ 6:1-9.6:1-7:3:80-92 and space times of $6-252 \mathrm{gh} \mathrm{mol}^{-1}$ (based on ethylene). Ex situ characterization by X-ray diffraction, electron microscopy, and X-ray photoelectron spectroscopy reveal that the oxide forms of all compounds, except $\mathrm{CeO}_{2}$, transform into their respective (oxy)chloride. Among all studied systems, $\mathrm{CeO}_{2}$ shows the highest activity but suffers from combustion forming $\mathrm{CO}_{x}$, while europium oxychloride $(\mathrm{EuOCl})$ leads to the best vinyl chloride selectivity of $96 \%$ at $20 \% \mathrm{C}_{2} \mathrm{H}_{4}$ conversion for over $100 \mathrm{~h}$ on stream. Temperature-programmed reduction with $\mathrm{H}_{2}$, temperature-programmed desorption of $\mathrm{NH}_{3}$, and oxidation tests $\left(\mathrm{C}_{2} \mathrm{H}_{4}\right.$, CO, and $\mathrm{HCl}$ oxidation) unravel the unique balance of mild redox and enhanced acid properties of EuOCI compared to $\mathrm{CeO}_{2}$, which suppress over-oxidation and boost ethylene dichloride dehydrochlorination. Strategies to couple the excellent selectivity of EuOCI with the high activity of $\mathrm{CeO}_{2}$ are demonstrated through the synthesis of homogeneous europium-cerium mixed oxides, combining two functions on a single surface. In addition, the engineering of a dual-bed reactor, integrating a $\mathrm{CeO}_{2}$ bed first to produce ethylene dichloride in high yield which is subsequently transformed to vinyl chloride over EuOCl leads to vinyl chloride yields of up to $30 \%$ per pass. These very promising findings constitute a crucial step for process intensification of polyvinyl chloride production and exploring the potential of rare-earth compounds in industrially-relevant reactions.

Keywords: ethylene oxychlorination, lanthanides, europium oxychloride, vinyl chloride monomer, bifunctional catalyst, process intensification 


\section{Introduction}

Polyvinyl chloride (PVC, 44 Mton, annual global growth rate of $3.2 \%$ ) is an integral part of modern society owing to its widespread applications that improve our everyday life $[1,2]$. Its monomer, chloroethene (commonly known as vinyl chloride and hereafter denoted as VCM), was first produced on a commercial scale in the 1920s through acetylene hydrochlorination over mercuric chloride catalysts, which still is the main production method in countries such as China, due to cheap availability of coal from which acetylene is produced [3,4]. However, the increasing demand for PVC and rising price of acetylene in the late 1950s prompted a shift in the feedstock to the more economical ethylene in the United States and Europe [3]. Since then, VCM is predominantly produced via a two-step process involving the selective oxychlorination of ethene (commonly known as ethylene) to 1,2-dichloroethane (commonly known as ethylene dichloride and hereafter denoted as EDC) over promoted $\mathrm{CuCl}_{2} / \gamma-\mathrm{Al}_{2} \mathrm{O}_{3}$ catalysts in fluidized-bed reactors $(T=473-573 \mathrm{~K}, P=1-10 \mathrm{bar})$ and the subsequent thermal cracking of EDC to $\operatorname{VCM}(T=773-873 \mathrm{~K}, P=25-35$ bar) $[3,4,5]$. The greatest limitations of the current process are the stability issues faced by the copper catalyst, and the limited per pass conversion (50-60\% with VCM selectivity >98\%) and high energy demand of the thermal cracking [3]. Despite continued efforts to optimize the robustness of the catalyst by doping with additives such as alkali ( $\mathrm{Li}, \mathrm{Na}, \mathrm{K})$, alkaline earth $(\mathrm{Mg}, \mathrm{Ca})$, and rare earth metals ( $\mathrm{La}, \mathrm{Ce})$, the copper chloride phase is still prone to volatilization and particle agglomeration [6-10]. Besides, the possible intensification of VCM production by integration of the oxychlorination and dehydrochlorination reactions as a one-step process requires a novel catalyst which can combine two functions.

In order to achieve this goal, new materials such as non-halide copper containing catalysts [11] and lanthanide (oxy)chlorides [12], particularly lanthanum oxychlorides, have been reported in the patent literature. However, none of these systems is realized on an industrial scale, most likely due to the low per pass VCM yields and/or stability hurdles faced by these catalysts. Recently, we have uncovered the high stability and remarkable yield of 
chlorinated compounds ( $25 \%$ VCM, $25 \%$ EDC) over $\mathrm{CeO}_{2}$. This outstanding performance was attributed to the integration of both redox sites, which catalyze the ethylene oxychlorination to EDC, and acid sites, responsible for the dehydrochlorination of EDC to VCM, on the same catalyst surface.

In spite of these encouraging results, $\mathrm{CeO}_{2}$ offers significant margins for improvement. In particular, a considerable amount of over-chlorinated compounds (1,2-dichloroethene, commonly known as 1,2-dichloroethylene and hereafter denoted as 1,2-DCE) and combustion products $\left(\mathrm{CO}_{x}\right)$ were also formed, decreasing the overall selectivity of EDC and VCM. Moreover, only moderate dehydrochlorination activity was observed. Thus, it can be anticipated that materials exhibiting milder oxidative properties and higher density of strong cites than ceria could lead to enhanced performance. Surprisingly, despite their extensive use as dopants of the $\mathrm{CuCl}_{2} / \gamma-\mathrm{Al}_{2} \mathrm{O}_{3}$ catalysts, lanthanide compounds were never systematically investigated as the main active phase for the conversion of ethylene to VCM. Besides, they were investigated in several other catalyst formulations mainly as dopants and supports [14-18], with the exception of cerium oxide and lanthanum oxide (or (oxy)chloride) which are also studied as the primary catalytic phase in oxidative processes, including $\mathrm{CO}$ oxidation [19,20], isobutane oxidation [21], $\mathrm{HCl}$ oxidation [22,23], methane oxidative coupling [24], selective reduction of nitrogen oxides [19,25], and methane oxychlorination [26,27].

Herein, the comparison of the performance of a broad set of the most abundant rareearth compounds leads to the discovery of the exceptional performance of europium oxychloride, exhibiting $96 \%$ VCM selectivity at $20 \%$ conversion for over $100 \mathrm{~h}$ on stream. Structural, redox, and acidic properties are investigated to rationalize the superior performance of europium oxychloride with respect to other lanthanides and parametric studies give insight to the distribution of products. In order to attain superior VCM yields, this novel active phase is combined with the high activity of $\mathrm{CeO}_{2}$ by synthesis of mixed oxides and through dual-bed reactor concepts. This study comprises the first practically-relevant application of europium in heterogeneous catalysis and the materials presented here have 
great potential to be explored in challenging catalyzed reactions, particularly towards the functionalization of hydrocarbons.

\section{Experimental methods}

\subsection{Catalyst preparation}

Commercial $\mathrm{La}_{2} \mathrm{O}_{3}$ (Alfa Aesar, 99.99\%), $\mathrm{Pr}_{2} \mathrm{O}_{3}$ (Alfa Aesar, 99.9\%), $\mathrm{Nd}_{2} \mathrm{O}_{3}$ (SigmaAldrich, 99.9\%), $\mathrm{Sm}_{2} \mathrm{O}_{3}$ (Sigma-Aldrich, 99.9\%), $\mathrm{Eu}_{2} \mathrm{O}_{3}$ (Sigma-Aldrich, 99.5\%), $\mathrm{Gd}_{2} \mathrm{O}_{3}$ (Alfa Aesar, 99.99\%), $\mathrm{Tb}_{2} \mathrm{O}_{3}$ (Strem Chemicals, 99.9\%), $\mathrm{Dy}_{2} \mathrm{O}_{3}$ (ABCR, 99.99\%), $\mathrm{Ho}_{2} \mathrm{O}_{3}$ (Fluka Chemie, 99.9\%), and $\mathrm{Er}_{2} \mathrm{O}_{3}$ (Fluka Chemie, 99.9\%) were calcined at $773 \mathrm{~K}$, and $\mathrm{CeO}_{2}$ (Sigma-Aldrich, 99.9\%) at $773 \mathrm{~K}$ and $1173 \mathrm{~K}$ in static air using a heating rate of $5 \mathrm{~K} \mathrm{~min}^{-1}$ and an isothermal step of $5 \mathrm{~h}$ prior to their use in catalytic studies. Analysis by X-ray diffraction revealed that the commercial praseodymium oxide actually consisted of $\mathrm{Pr}_{4} \mathrm{O}_{7}$ and thus it is denoted as such herein. Europium oxide $\left(\mathrm{Eu}_{2} \mathrm{O}_{3}-\mathrm{p}-T_{\text {cal }}\right.$, where $T_{\text {cal }}$ denotes the calcination temperature in $\mathrm{K})$, cerium oxide $\left(\mathrm{CeO}_{2}-\mathrm{p}-T_{\text {cal }}\right)$, and mixed europium-cerium oxides $\left(\mathrm{Eu}_{x} \mathrm{Ce}_{1-x} \mathrm{O}_{2-0.5 x}-\mathrm{cp}-T_{\text {cal }}\right.$, where $x$ represents the molar fraction of $\mathrm{Eu}$ in the range of 0.3-0.9) were synthesized by precipitation ( $p$, single oxides) and coprecipitation ( $c p$, mixed oxides) following a protocol reported elsewhere [13]. Briefly, the metal nitrates $\left(\mathrm{Eu}_{2}\left(\mathrm{NO}_{3}\right)_{3} \cdot 6 \mathrm{H}_{2} \mathrm{O}(\mathrm{ABCR}, 99.9 \%)\right.$ for $\mathrm{Eu}_{2} \mathrm{O}_{3}-\mathrm{p}, \mathrm{Ce}\left(\mathrm{NO}_{3}\right)_{3} \cdot 6 \mathrm{H}_{2} \mathrm{O}(\mathrm{ABCR}, 99.9 \%)$ for $\mathrm{CeO}_{2}-\mathrm{p}$, or mixtures for $\mathrm{Eu}_{x} \mathrm{Ce}_{1-x} \mathrm{O}_{2-0.5 x}-\mathrm{cp}$ ) were dissolved in deionized water under stirring and $\mathrm{H}_{2} \mathrm{O}_{2}$ (Acros Organics, 35\%) was added to the solution to obtain a molar $\mathrm{H}_{2} \mathrm{O}_{2}: M$ ratio of 3 $(M=\mathrm{Eu}, \mathrm{Ce}$, or $\mathrm{Eu}+\mathrm{Ce})$. The coprecipitation was achieved by the dropwise addition of aqueous $\mathrm{NH}_{4} \mathrm{OH}$ (Sigma-Aldrich, 30\%) until a $\mathrm{pH}$ of 10.5 was reached. The slurry was stirred for $4 \mathrm{~h}$ and washed with deionized water. Upon filtration, the precipitate was dried at $393 \mathrm{~K}$ for $12 \mathrm{~h}$ and calcined at $773 \mathrm{~K}$ for $\mathrm{CeO}_{2}-\mathrm{p}, 773-1173 \mathrm{~K}$ for $\mathrm{Eu}_{2} \mathrm{O}_{3}-\mathrm{p}$, and $773 \mathrm{~K}$ for $\mathrm{Eu}_{x} \mathrm{Ce}_{1-x} \mathrm{O}_{2-0.5 x} \mathrm{cp}$ in flowing air using a heating rate of $5 \mathrm{~K} \mathrm{~min}^{-1}$ and an isothermal step of $5 \mathrm{~h}$. 


\subsection{Characterization}

The metal content was determined by X-ray fluorescence (XRF) spectroscopy using an Orbis PC Micro-EDXRF analyzer with a Rh source $(15 \mathrm{kV}, 500 \mu \mathrm{A})$ and a silicon drift detector. Powder X-ray diffraction (XRD) was measured using a PANalytical X'Pert PROMPD diffractometer and Cu-K $\alpha$ radiation $(\lambda=0.15418 \mathrm{~nm})$. The data was recorded in the $10-70^{\circ} 2 \theta$ range with an angular step size of $0.017^{\circ}$ and a continuing time of $0.26 \mathrm{~s}$ per step. $\mathrm{N}_{2}$ sorption at $77 \mathrm{~K}$ was measured in a Quantachrome Quadrasorb-SI analyzer. Prior to the measurements, the samples were outgassed to 50 mbar at $573 \mathrm{~K}$ for $3 \mathrm{~h}$. The BrunauerEmmett-Teller (BET) method [28] was applied to calculate the total surface area, $S_{\mathrm{BET}}$, in $\mathrm{m}^{2} \mathrm{~g}^{-1}$. High-resolution transmission electron microscopy (HRTEM) and elemental mapping using energy-dispersive $\mathrm{X}$-ray spectroscopy (EDX) were conducted on a FEI Talos microscope operated at $200 \mathrm{kV}$. All samples were dispersed as dry powders onto lacey carbon coated nickel or molybdenum grids. X-ray photoelectron spectroscopy (XPS) measurements were performed on a Physical Electronics Quantum 2000 X-ray photoelectron spectrometer using monochromatic Al-K $\alpha$ radiation generated from an electron beam operated at $15 \mathrm{kV}$, and equipped with a hemispherical capacitor electronenergy analyzer. The powdered sample was firmly pressed onto the foil. The area analyzed was $150 \mu \mathrm{m}$ in diameter and the electron take-off angle was $45^{\circ}$. The pass energy used for the detailed spectra of the $\mathrm{C} 1 s, \mathrm{O} 1 s, \mathrm{Cl} 2 p$, Eu $3 d$, Eu $4 d$, and $\mathrm{Ce} 3 d$ core levels was $46.95 \mathrm{eV}$ to yield a total analyzer energy resolution of $0.95 \mathrm{eV}$. The spectrometer energy scale was calibrated for the Au $4 f$ electrons to be at $84.0 \pm 0.1 \mathrm{eV}$. Partial compensation of surface charging during spectra acquisition was obtained by the simultaneous operation of electron and argon ion neutralizers. Elemental concentrations are given in atomic percent using the measured photoelectron peak areas after Shirley background subtraction and the built-in sensitivity factors for calculation. Temperature-programmed desorption of ammonia $\left(\mathrm{NH}_{3}\right.$-TPD) and temperature-programmed reduction with hydrogen $\left(\mathrm{H}_{2}\right.$-TPR) were performed using a Micromeritics Autochem II 2920 unit equipped with a thermal conductivity detector 
coupled to a MKS Cirrus 2 mass spectrometer. The powder sample $(0.1 \mathrm{~g})$ was loaded into a U-shaped quartz micro-reactor, pretreated in $\mathrm{He}\left(20 \mathrm{~cm}^{3} \mathrm{STP} \mathrm{min}^{-1}\right)$ at $573 \mathrm{~K}$ for $3 \mathrm{~h}$, and cooled to $373 \mathrm{~K}$ in He. For $\mathrm{NH}_{3}$-TPD experiments, ammonia was chemisorbed at $473 \mathrm{~K}$ in three consecutive cycles of saturation with 5 vol. $\% \mathrm{NH}_{3} / \mathrm{He}\left(20 \mathrm{~cm}^{3} \mathrm{STP} \mathrm{min}^{-1}\right)$ for $30 \mathrm{~min}$ followed by purging with $\mathrm{He}\left(20 \mathrm{~cm}^{3} \mathrm{STP} \mathrm{min}^{-1}\right)$ at the same temperature for $30 \mathrm{~min}$. Desorption of $\mathrm{NH}_{3}$ was monitored in the range of $473-1273 \mathrm{~K}$ using a heating rate of $20 \mathrm{~K} \mathrm{~min}^{-1}$ and a He flow of $20 \mathrm{~cm}^{3} \mathrm{STP} \mathrm{min}^{-1}$. For $\mathrm{H}_{2}$-TPR experiments, the sample was pretreated in $\mathrm{He}\left(20 \mathrm{~cm}^{3} \mathrm{STP} \mathrm{min}^{-1}\right)$ at $423 \mathrm{~K}$ for $1 \mathrm{~h}$, and cooled to room temperature followed by ramping the temperature at $10 \mathrm{~K} \mathrm{~min}^{-1}$ up to $1273 \mathrm{~K}$ in $5 \mathrm{vol} . \% \mathrm{H}_{2}$ $\left(20 \mathrm{~cm}^{3}\right.$ STP $\left.\mathrm{min}^{-1}\right)$.

\subsection{Catalytic tests}

The gas-phase oxychlorination of ethylene was investigated at ambient pressure in a continuous-flow fixed-bed reactor (Scheme 1). The set-up consists of (I) mass flow controllers to feed $\mathrm{C}_{2} \mathrm{H}_{4}$ (PanGas, $20.15 \%$ in $\mathrm{He}$ ), $\mathrm{HCl}$ (Air Liquide, purity 2.8, anhydrous), $\mathrm{O}_{2}$ (Messer, 10.06\% in He), He (PanGas, purity 5.0) as a carrier gas, and Ar (PanGas, purity 5.0) as an internal standard, (ii) a syringe pump (Nexus 6000, Chemyx) to feed EDC (Fluka, 99.5\%), (iii) a vaporizer operated at $403 \mathrm{~K}$ accommodating a quartz $\mathrm{T}$-connector filled with glass beads to vaporize EDC, (iv) an electrically heated oven hosting a quartz micro-reactor equipped with a K-type thermocouple whose tip reaches the center of the catalyst bed, $(v)$ downstream heat tracing to avoid any condensation of the reactants and products, and $(\mathrm{VI}) \mathrm{a}$ gas chromatograph coupled to a mass spectrometer (GC-MS) for on-line analysis. The effluent stream was neutralized by passing it through an impinging bottle containing an aqueous $\mathrm{NaOH}$ solution $(1 \mathrm{M})$. The catalyst $\left(W_{\text {cat }}=0.25-2 \mathrm{~g}\right.$, particle size, $\left.d_{\mathrm{p}}=0.4-0.6 \mathrm{~mm}\right)$ was loaded in the micro-reactor (10 mm inner diameter) and pretreated in $\mathrm{He}$ at $473 \mathrm{~K}$ for 30 min. Thereafter, a total flow $\left(F_{\mathrm{T}}\right)$ of $100 \mathrm{~cm}^{3} \mathrm{STP} \min ^{-1}$ containing $3-6$ vol.\% $\mathrm{C}_{2} \mathrm{H}_{4}, 1-$ 9.6 vol. $\% \mathrm{HCl}, 1-7$ vol. $\% \mathrm{O}_{2}$, and 3 vol.\% $\mathrm{Ar}$ as internal standard, balanced in He was fed to 
the reactor at a bed temperature $(T)$ of $623-773 \mathrm{~K}$ and pressure $(P)$ of 1 bar. Note that relatively low feed concentrations were selected to prevent corrosion, enable safe handling, and minimize the formation of hot spots in the catalyst bed due to the high reaction exothermicity. Temperature measurements in a reference experiment on $\mathrm{CeO}_{2}-1173$ (at $31 \% \mathrm{C}_{2} \mathrm{H}_{4}$ conversion), evidenced a temperature gradient of $0.9 \mathrm{~K}$ across the bed when the temperature in the center of the catalyst bed was set to $673 \mathrm{~K}$ (Scheme 1). The standard conditions of 3 vol.\% $\mathrm{C}_{2} \mathrm{H}_{4}, 4.8 \mathrm{vol} . \% \mathrm{HCl}$, and 3 vol.\% $\mathrm{O}_{2}$ were chosen based on the literature $[8,13]$. The space time, defined as the ratio of the catalyst mass and the inlet molar flow of ethylene as the limiting reactant, $W_{\text {cat }} / \dot{n}^{0}\left(\mathrm{C}_{2} \mathrm{H}_{4}\right.$ was varied in the range of 6 $252 \mathrm{~g} \mathrm{~h} \mathrm{~mol}^{-1}$. In the dehydrochlorination tests, 1.5 vol.\% EDC was fed to the catalyst $\left(W_{\text {cat }}=0.5 \mathrm{~g}, d_{\mathrm{p}}=0.4-0.6 \mathrm{~mm}\right)$ using He as carrier gas $\left(F_{\mathrm{T}}=100 \mathrm{~cm}^{3} \mathrm{STP} \mathrm{min}^{-1}\right)$ with or without addition of $\mathrm{HCl}$ (4.8 vol.\%) and $\mathrm{O}_{2} \quad(3 \mathrm{vol} . \%)$ at $T=523-773 \mathrm{~K}$ and $W_{\text {cat }} / \dot{n}^{0}(\mathrm{EDC})=126 \mathrm{~g} \mathrm{~h} \mathrm{~mol}^{-1}$. Prior to the analysis of the reaction mixtures, the catalysts were equilibrated for at least $1 \mathrm{~h}$ under each condition. The gas composition at the reactor outlet containing reactants $\left(\mathrm{C}_{2} \mathrm{H}_{4}, \mathrm{O}_{2}, \mathrm{HCl}\right)$ and products (EDC, VCM, 1,2-DCE, CO, $\mathrm{CO}_{2}$ ) was analyzed online using a gas chromatograph equipped with a GS-CarbonPLOT column coupled to a mass spectrometer (Agilent GC 7890B, Agilent MSD 5977A) with a triple-axis detector and an electron multiplier. A representative chromatogram is depicted as an inset in Scheme 1. In the oxidation tests, $\mathrm{C}_{2} \mathrm{H}_{4}$ (3 vol.\%), $\mathrm{CO}$ (2.5 vol.\%), or $\mathrm{HCl}\left(3\right.$ vol.\%) and $\mathrm{O}_{2}$ were fed in a 1:1 volumetric ratio. In the $\mathrm{HCl}$ oxidation tests, the $\mathrm{Cl}_{2}$ production was quantified by offline iodometric titration (using a Mettler Toledo G20 Compact Titrator) of triiodide, formed by purging the $\mathrm{Cl}_{2}$ containing reactor outlet through an aqueous $\mathrm{KI}$ (SigmaAldrich, 99.5\%) solution $(0.1 \mathrm{M})$, with $0.01 \mathrm{M}$ sodium thiosulfate solution (Sigma-Aldrich, 99.99\%). The conversion of $\mathrm{HCl}, X(\mathrm{HCl})$, was calculated using Eq. 1,

$$
X(\mathrm{HCl})=\frac{2 x_{\mathrm{Cl}_{2}, \text { outlet }}}{x_{\mathrm{HCl}, \text { inlet }}} \cdot 100, \%
$$


where $x_{\mathrm{HCl} \text {,inlet }}$ and $x_{\mathrm{Cl}_{2} \text {,outlet }}$ denote the volumetric concentration of $\mathrm{HCl}$ and $\mathrm{Cl}_{2}$ at the reactor inlet and outlet, respectively. The conversion of carbon containing reactant, $X(I)$, where $i$ denotes $\mathrm{C}_{2} \mathrm{H}_{4}$ or $\mathrm{CO}$, was calculated according to Eq. 2,

$$
X(i)=\frac{x_{i, \text { inlet }}-x_{i, \text { outlet }}}{x_{i, \text { inlet }}} \cdot 100, \%
$$

where $x_{i, \text { inlet }}$ and $x_{i, \text { outlet }}$ denote the volumetric concentration of $i$ at the reactor inlet and outlet, respectively. The selectivity and yield of a reaction product $j, S(j)$ and $Y(j)$, were calculated according to Eqs. 3 and 4,

$$
\begin{gathered}
S(j)=\frac{x_{j} / v_{j}}{\sum x_{j} / v_{j}} \cdot 100, \% \\
Y(j)=\frac{X(i) \cdot S(j)}{100}, \%
\end{gathered}
$$

where $x_{j}$ and $v_{j}$ denote the volumetric concentrations of product $j$ at the reactor outlet and the corresponding stoichiometric factor with respect to the number of carbon atoms, respectively (e.g., $\mathrm{C}_{2} \mathrm{H}_{4}+2 \mathrm{O}_{2} \rightarrow 2 \mathrm{CO}+2 \mathrm{H}_{2} \mathrm{O}, v_{\mathrm{CO}}=2$ ). The rate of VCM production, $r(\mathrm{VCM})$, and the rate of ethylene consumption, $r\left(\mathrm{C}_{2} \mathrm{H}_{4}\right)$ were calculated using Eq. 5 and $\mathbf{6}$,

$$
\begin{gathered}
r(\mathrm{VCM})=\frac{x_{\mathrm{C}_{2} \mathrm{H}_{4} \text {,inlet }} \cdot F_{\mathrm{T}} \cdot X\left(\mathrm{C}_{2} \mathrm{H}_{4}\right) / 100 \cdot P \cdot S(\mathrm{VCM}) / 100}{R \cdot T_{\mathrm{STP}} \cdot W_{\text {cat }} \cdot S_{\mathrm{BET}}}, \mathrm{mol} \mathrm{h}^{-1} \mathrm{~m}^{-2} \\
r\left(\mathrm{C}_{2} \mathrm{H}_{4}\right)=\frac{x_{\mathrm{C}_{2} \mathrm{H}_{4} \text {,inlet }} \cdot F_{\mathrm{T}} \cdot X\left(\mathrm{C}_{2} \mathrm{H}_{4}\right) / 100 \cdot P}{R \cdot T_{\mathrm{STP}} \cdot W_{\text {cat }} \cdot S_{\mathrm{BET}}}, \mathrm{mol} \mathrm{h}^{-1} \mathrm{~m}^{-2}
\end{gathered}
$$

where $x_{\mathrm{C}_{2} \mathrm{H}_{4} \text {,inlet }}, \mathrm{R}$, and $T_{\mathrm{STP}}$, denote volumetric reactor inlet $\mathrm{C}_{2} \mathrm{H}_{4}$ concentration, gas constant, and temperature at standard conditions, catalyst mass, and specific surface area, respectively. The carbon mass balance error $\varepsilon_{\mathrm{C}}$ was determined using Eq. 7,

$$
\varepsilon_{\mathrm{C}}=\left|\frac{\sum x_{i, j, \text { inlet }} / v_{i, j, \text { inlet }}-\sum x_{i, j, \text { outlet }} / v_{i, j, \text { outlet }}}{\sum x_{i, j, \text { inlet }} / v_{i, j, \text { inlet }}}\right| \cdot 100, \%
$$

where $x_{i, j}$ and $v_{i, j}$ denote the concentration of reactant $i$ or product $j$ at the reactor inlet or outlet and the corresponding stoichiometric factor with respect to the number of carbon atoms, respectively. Each catalytic data point reported is an average of at least three measurements. The carbon mass balance in all catalytic tests closed at $96 \%$ or higher. After the tests, the catalyst bed was quenched to room temperature in He flow. 


\section{Results and discussion}

\subsection{Performance of lanthanide compounds in ethylene oxychlorination}

The lanthanide oxides evaluated in this study were characterized by XRF (Fig. S1) and XRD (Fig. S2) to confirm their compositional and phase purity. All results coincided with the manufacturers specifications except in the case of praseodymium, which was found to be present mainly in the form of $\mathrm{Pr}_{4} \mathrm{O}_{7}$ rather than $\mathrm{Pr}_{2} \mathrm{O}_{3}$. Besides, the post-reaction structural analysis revealed that all samples except $\mathrm{CeO}_{2}$ undergo phase transitions to their respective (oxy)chloride phase (vide infra; e.g. $\mathrm{Eu}_{2} \mathrm{O}_{3}$ transforms to $\mathrm{EuOCl}$ ). For this reason, the catalysts are denoted according to the crystalline phase evidenced by XRD in the equilibrated materials (after treatment for at least $1 \mathrm{~h}$ under reaction conditions).

Comparative assessment in ethylene oxychlorination (Fig. 1), revealed that the rare earth materials can be classified into three groups according to their performance. The first (SmOCl, $\mathrm{ErCl}_{3}, \mathrm{TbOCl}$, and $\mathrm{HoOCl}$ ) and second (PrOCl, DyOCl, $\mathrm{GdOCl}, \mathrm{NdCl}_{3}, \mathrm{LaCl}_{3}$ ) both display only minor activity, and are differentiated by the observation of chlorinated products (EDC or VCM) which are only formed over the latter group. In contrast, the third group, comprising $\mathrm{CeO}_{2}$ and $\mathrm{EuOCl}$, stands out, exhibiting notably higher $\mathrm{C}_{2} \mathrm{H}_{4}$ conversion and selectivity to chlorinated products than either of the other groups. $\mathrm{CeO}_{2}$, which was previously studied in this reaction, demonstrated the highest yield of chlorinated compounds. On the other hand, EuOCI interestingly showed the highest selectivity to VCM (51\% versus $30 \%$ over $\mathrm{CeO}_{2}$ at 12 and $26 \% \mathrm{C}_{2} \mathrm{H}_{4}$ conversion, respectively) and no formation of $\mathrm{CO}_{2}$. Two advantageous features of EuOCl can be highlighted: the suppressed $\mathrm{CO}_{2}$ formation indicates an inherently lower reducibility of $\mathrm{EuOCl}$ with respect to $\mathrm{CeO}_{2}$ while still maintaining the ability to form EDC and the low EDC selectivity over EuOCl evidences that more than $90 \%$ of the EDC formed is directly transformed to VCM. In addition, EuOCl shows a 1.5 fold higher relative ethylene conversion per unit surface area of the equilibrated sample as determined by $\mathrm{N}_{2}$ sorption (Table 1) than $\mathrm{CeO}_{2}$. In fact, comparison of the surface 
normalized rate of VCM production as a function of the inverse of temperature (Fig. 1, inset) reveals that $\mathrm{EuOCl}$ outperforms $\mathrm{CeO}_{2}$ in the whole temperature range.

Previously [13], we showed that the ethylene oxychlorination performance of $\mathrm{CeO}_{2}$ could be enhanced through the preparation of materials with higher surface areas by precipitation. Following this strategy, a series of europium-based catalysts (EuOCl-p- $T_{\text {cal }}$, where $T_{\text {cal }}$ denotes the calcination temperature) were prepared with surface areas comparable to that of $\mathrm{CeO}_{2}$. Surprisingly, however, these samples did not lead to the expected increase in conversion, but completely suppressed the oxidation reaction to $\mathrm{CO}$ and largely increased the yields of EDC and VCM (Fig. 1), which were highest over EuOCI-p-973. In this case, EuOCl-p-973 was found to be one order of magnitude more reactive than $\mathrm{CeO}_{2}$ and comparable to $\mathrm{EuOCl}$ in terms of surface normalized rate (Fig. 1, inset).

\subsection{Catalyst evolution in ethylene oxychlorination}

Analysis of the structure, composition, porosity, and surface properties of the equilibrated catalysts provides insight into the trends observed during the comparative evaluation in ethylene oxychlorination. As mentioned (vide supra), phase transformations were observed in all of the catalysts after evaluation in the ethylene oxychlorination reaction, except $\mathrm{CeO}_{2}$. Nonetheless, this phase evolution should be regarded as an equilibration step leading to the successful formation of the active (oxy)chloride phase rather than proof of instability. In fact, no catalyst volatilization was evidenced. Comparison by XRD (Figs. 2, S2) identifies three different degrees of transformation, encompassing the preservation of the bulk oxide $\left(\mathrm{CeO}_{2}\right)$ $[13,22]$, the formation of an oxychloride $(\mathrm{SmOCl}, \mathrm{TbOCl}, \mathrm{HoOCl}, \mathrm{PrOCl}, \mathrm{EuOCl})$, and the complete transformation to the chloride phase $\left(\mathrm{ErCl}_{3}, \mathrm{NdCl}_{3}, \mathrm{LaCl}_{3}\right)$. Despite exhibiting distinct performance, only a single europium oxychloride phase is observed in EuOCI-p-973 and EuOCl. Slightly sharper reflections in the latter reflect increased average particle size, which is in line with lower surface area. A Scherrer-based analysis confirms an average crystal size of $31 \mathrm{~nm}$ for EuOCI in comparison with $13 \mathrm{~nm}$ for the EuOCl-p-973 sample. 
Examination of $\mathrm{LaCl}_{3}, \mathrm{EuOCl}$, and $\mathrm{CeO}_{2}$ by $\mathrm{TEM}$ and elemental mapping clearly revealed the different extent of chlorination in these samples. $\mathrm{LaCl}_{3}$ (Fig. 3a), which fully chlorinates upon equilibration under ethylene oxychlorination conditions, comprises large agglomerates of between $100-200 \mathrm{~nm}$ diameter. The relative intensity of the $\mathrm{Cl}$ and $\mathrm{La}$ lines in the EDX spectrum of ca. 3 agrees well with the stoichiometry of the metal chloride. Comparatively, EuOCl as well as EuOCl-p-973 (Fig. 3b,c) features much smaller particles of ca. $40 \mathrm{~nm}$ in diameter and a $\mathrm{Cl}: \mathrm{Eu}$ intensity ratio close to unity, as expected from a pure oxychloride phase. In both cases, no considerable change in crystal size is observed between the as prepared and equilibrated materials. Finally, $\mathrm{CeO}_{2}$ evidences even smaller nanoparticles of 10-20 nm (as prepared: 5-10 nm) in diameter and exhibits only a minor chlorine peak in the EDX spectrum (Fig. 3d, inset), consistent with the low intensity of this element in the corresponding map and the preservation of the oxide phase evidenced by XRD. To detect possible differences in the surface and bulk composition, XPS analysis was conducted for the as-prepared $\mathrm{Eu}_{2} \mathrm{O}_{3}-\mathrm{p}-973$, which evidences a Eu $4 d$ core level band structure composed of the Eu $4 d_{3 / 2}$ and Eu $4 d_{5 / 2}$ peaks, characteristic of $\mathrm{Eu}_{2} \mathrm{O}_{3}$ (Fig. 4a) $[29,30]$. Upon use in ethylene oxychlorination, both of these peaks were shifted to higher binding energy by $2 \mathrm{eV}$, pointing to the presence of neighboring atoms of high electronegativity [29]. A signal detected in the survey spectrum at $198.5 \mathrm{eV}$ [31] in the $\mathrm{Cl} 2 p$ region unequivocally confirmed the presence of chlorine at the surface (Fig. $\mathbf{4 b}$ ). In fact, the surface atomic concentrations of $\mathrm{Eu}, \mathrm{O}$, and $\mathrm{Cl}$ were determined to be 33,36 , and $30 \%$, respectively, which is close to the stoichiometry of the oxychloride phase.

Overall, these results demonstrate that ethylene oxychlorination over the lanthanide compounds studied is essentially catalyzed by the oxychloride or chloride phase, including in the case of $\mathrm{CeO}_{2}$ in which chloride species exist at the surface. However, there are no detectable structural differences between $\mathrm{EuOCI}$ and EuOCI-p-973 that would explain their disparity in selectivity. As on $\mathrm{CeO}_{2}$ the suppression of combustion and the formation of VCM were linked to moderated oxidative properties (catalyzing ethylene oxychlorination to EDC) 
and the presence of acid sites (needed for EDC dehydrochlorination to VCM [32]), the properties of EuOCl-p-973 and $\mathrm{CeO}_{2}$ were investigated by $\mathrm{H}_{2}$-TPR and $\mathrm{NH}_{3}$-TPD. PrOCl was also studied as a moderately active and unselective reference.

The $\mathrm{H}_{2}$-TPR profile of $\mathrm{CeO}_{2}$ (Fig. 5a) shows two $\mathrm{H}_{2}$ consumption peaks at 761 and $1090 \mathrm{~K}$, which are attributed to the reduction of labile surface or near-surface oxygen species and the bulk, respectively $[32,34]$. This very much resembles the analysis of the asprepared $\mathrm{CeO}_{2}$ samples [22] and indicates that the reducibility of this oxide is not significantly altered under reaction conditions. $\operatorname{Pr}_{4} \mathrm{O}_{7}$ displays a $\mathrm{H}_{2}$ consumption peak centered at $978 \mathrm{~K}$, however, no $\mathrm{H}_{2}$ consumption is observed for its analogue PrOCl, indicating that the oxychloride is irreducible in this temperature range. This explains the negligible yields of VCM and CO, observed over this catalyst, which are comparable to the inactive materials. $\mathrm{Eu}_{2} \mathrm{O}_{3}-\mathrm{p}-973$ evidences a broad $\mathrm{H}_{2}$ consumption peak in the range of 882 $1197 \mathrm{~K}$, while EuOCl-p-973 shows $\mathrm{H}_{2}$ consumption at significantly higher temperature (similar trend for $\mathrm{Eu}_{2} \mathrm{O}_{3}$ and $\mathrm{EuOCl}$ ). Thus, the diminished reducibility of europium oxychlorides compared to $\mathrm{CeO}_{2}$ is responsible for the lower activity and most importantly the suppression of combustion. However, it is still sufficient to catalyze the formation of EDC.

$\mathrm{NH}_{3}$-TPD analyses confirmed that the equilibrated $\mathrm{CeO}_{2}$ and EuOCI-p-973 catalysts both exhibit significant $\mathrm{NH}_{3}$ desorption in the range of $525-775 \mathrm{~K}$ (Fig. 5b), evidencing the presence of acid sites. This is in line with previous studies on $\mathrm{CeO}_{2}$ after treatment under chlorination conditions $[13,35]$. The lower acidity of EuOCI with respect to EuOCl-p-973 is also in accordance with the lower VCM selectivity of the former. Surprisingly, PrOCl shows the highest amount of acid sites by far, which causes the complete transformation of any EDC produced to VCM. Quantification of the amount of ammonia evolved from the two materials with highest VCM yields reveals a significantly higher acid site density in EuOCI-p$973\left(1.92 \mu \mathrm{mol} \mathrm{g}{ }^{-1}\right)$ than $\mathrm{CeO}_{2}\left(1.45 \mu \mathrm{mol} \mathrm{g}^{-1}\right)$, explaining the enhanced VCM formation over the former. 


\subsection{Influence of operating conditions}

In view of the unprecedented selectivity of EuOCl-p-973, the impact of reaction conditions (namely temperature, $\mathrm{HCl}$ and $\mathrm{O}_{2}$ feed contents, and contact time) on the conversion and product distribution was studied (Fig. 6). These results are compared with $\mathrm{CeO}_{2}$ calcined at $1173 \mathrm{~K}\left(\mathrm{CeO}_{2}-1173\right)$, which was previously reported in ethylene oxychlorination [13]. Both catalysts exhibit an increased conversion with temperature (Fig. 6a), but the enhancement is lower over EuOCl-p-973 than $\mathrm{CeO}_{2}$-1173. Accordingly, the apparent activation energy (determined from Arrhenius plots, Fig. S3) is slightly higher for $\mathrm{CeO}_{2}-1173\left(28 \mathrm{~kJ} \mathrm{~mol}^{-1}\right)$ than for EuOCl-p-973 (17 kJ mol$\left.{ }^{-1}\right)$. Considering the product distribution, the selectivity to VCM increases with reaction temperature over both catalysts, which correlates with a parallel decrease in the EDC selectivity. No $\mathrm{CO}_{x}$ formation is evidenced over EuOCl-p-973 up to $773 \mathrm{~K}$ at which point a minor amount of $\mathrm{CO}$ is observed, whereas $\mathrm{CeO}_{2}-1173$ suffers from over-oxidation above $673 \mathrm{~K}$, leading to ca. $50 \%$ selectivity to $\mathrm{CO}_{x}$ (at $50 \% \mathrm{C}_{2} \mathrm{H}_{4}$ conversion) at $773 \mathrm{~K}$. However, in this comparison of the effect of temperature on the selectivity patterns of the catalysts, the conversion levels differ due to the stronger activity dependence on temperature of $\mathrm{CeO}_{2}$ than that of $\mathrm{EuOCl}$. Therefore, to decouple the effect of temperature and conversion, the latter was raised by changing the space time at $723 \mathrm{~K}$ over both catalysts (Fig. 6d). Upon increasing the $\mathrm{C}_{2} \mathrm{H}_{4}$ conversion over EuOCl-p-973, the selectivity to VCM strongly increases and, reaching $100 \%$ at $25 \%$ conversion. The selectivity to EDC decreases in equal order, which is consistent with the successive transformation of ethylene to EDC and its dehydrochlorination to VCM. A qualitatively similar decrease of EDC selectivity is also observed over $\mathrm{CeO}_{2}-1173$ at comparable conversion levels. Nonetheless, the formation of combustion $\left(\mathrm{CO}_{x}\right)$ and over-chlorinated (1,2-DCE) products is enhanced instead of VCM.

Varying the feed composition also highlights significant differences in the behavior of the two catalysts. Neither the conversion nor the product distribution is significantly affected by the $\mathrm{HCl}$ or $\mathrm{O}_{2}$ feed contents within the investigated range (i.e. zero order with respect to $\mathrm{HCl}$ 
and $\mathrm{O}_{2}$ ) over EuOCl-p-973. In contrast, $\mathrm{CeO}_{2}-1173$ exhibits a positive linear activity trend with the $\mathrm{HCl}$ feed content and a second order dependency with respect to oxygen (Fig. 6b,c). Furthermore, the EDC selectivity increases with the $\mathrm{HCl}$ content in the feed over $\mathrm{CeO}_{2}-1173$, compensated by decreased $\mathrm{CO}_{x}$ formation. This is expected as a higher degree of chlorination lowers the oxidative strength of the $\mathrm{CeO}_{2}-1173$ surface $[13,22]$ and provides more available sites for chlorination. The inverse argument applies for raising the oxygen content, which favors combustion and lowers the selectivity to EDC linearly by decreasing the degree of surface chlorination [22]. Combining these results with the insights gained from the bulk and surface characterization, important differences between the two materials can be pointed out. Although $\mathrm{CeO}_{2}-1173$ preserves the bulk structure of the oxide, the reaction environment alters the nature of the surface from a more oxide- to a more chloridedominated structure, which have different oxidative properties. In contrast, once formed the surface structure of EuOCI-p-973 remains unaltered by the feed conditions. Thus, a change in reaction atmosphere only affects the thermodynamic equilibria, but not the nature of redox sites.

To further understand the selectivity patterns of catalysts in ethylene oxychlorination, the reaction was split into the four possible processes that can impact the VCM formation. These include the oxidation of $\mathrm{C}_{2} \mathrm{H}_{4}$ to $\mathrm{CO}_{x}, \mathrm{CO}$ to $\mathrm{CO}_{2}$, and $\mathrm{HCl}$ to $\mathrm{Cl}_{2}$, as well as the dehydrochlorination of EDC to VCM (Fig. 7). Each reaction was performed over equilibrated samples: $\mathrm{CeO}_{2}$ (exhibiting the highest activity), EuOCI-p-973 (attaining the highest VCM yield), and $\mathrm{PrOCl}$ (representative of samples exhibiting low activity and high $\mathrm{CO}$ formation). In $\mathrm{C}_{2} \mathrm{H}_{4}$ and $\mathrm{HCl}$ oxidation reactions, $\mathrm{CeO}_{2}$ is the most active material, especially at higher temperatures (Fig. 7a,b), which correlates with its higher reducibility (vide supra, Fig. 5a). PrOCl also shows activity for the oxidation of $\mathrm{C}_{2} \mathrm{H}_{4}$ and $\mathrm{CO}$, with similar or lower light-off temperatures compared to $\mathrm{CeO}_{2}$, respectively. Note that no $\mathrm{CO}_{2}$ was generated on $\mathrm{PrOCl}$ during ethylene oxychlorination, while in separate oxidation experiments it converted both $\mathrm{C}_{2} \mathrm{H}_{4}$ and $\mathrm{CO}$ to $\mathrm{CO}_{2}$. XRD analysis revealed that the PrOCl phase partially decomposes and 
re-transforms to the $\mathrm{Pr}_{4} \mathrm{O}_{7}$ phase during oxidation reactions in the absence of $\mathrm{HCl}$, which is again reducible (Figs. 5a, S4a,b) and thus causes the formation of $\mathrm{CO}_{x}$. The limited yield of chlorinated products formed on PrOCl (Fig. 1) is explained by its inability to release chlorine as seen from its negligible activity in $\mathrm{HCl}$ oxidation tests (Fig. 7c). In stark contrast to the above-mentioned systems, EuOCI-p-973 is essentially inactive for the $\mathrm{C}_{2} \mathrm{H}_{4}$ and $\mathrm{CO}$ oxidation reactions (Fig. 7a,b), preserves the $\mathrm{EuOCl}$ phase under oxidizing conditions (Fig. S4), and has moderate ability to transfer chlorine as evidenced by its mild $\mathrm{HCl}$ oxidation activity above $673 \mathrm{~K}$ (Fig. 7c). Thus, it appears that the stability of the oxychloride phase and the ability to release chlorine from the surface are key to suppressing the formation of undesired oxidation products and to chlorinate ethylene.

Finally, the dehydrochlorination of EDC to VCM, was investigated by feeding 1.5 vol.\% EDC without or with addition of 3 vol. $\% \mathrm{O}_{2}$ and 4.8 vol. $\% \mathrm{HCl}$ to the feed (Fig. $\mathbf{7 d}$ ). The EDC concentration was selected to simulate a $50 \%$ ethylene conversion to EDC. Furthermore, since $\mathrm{CeO}_{2}$ was known to yield a $90 \%$ conversion to VCM in mixed $\mathrm{EDC}: \mathrm{O}_{2}: \mathrm{HCl}$ feeds [13], a high EDC feed concentration was preferred to provide improved sensitivity to differences in the performance. Dehydrochlorination activity was observed in all cases. This differed from our previous study, in which $\mathrm{CeO}_{2}$ was found to be inactive in a pure EDC feed. The latter finding can be explained by the fact that in the present study, we evaluated the dehydrochlorination performance on catalysts equilibrated in ethylene oxychlorination, which increased the acidity of these samples. Albeit demonstrating a limited selectivity to chlorinated products in ethylene oxychlorination, PrOCl displays the best EDC dehydrochlorination performance, with or without cofeeding oxygen and $\mathrm{HCl}$, which can be linked to the highest density of acid sites evidenced in this material. However, the inferior performance of $\mathrm{PrOCl}$ in ethylene oxychlorination can be related to the low tendency of this catalyst to release chloride and it negligible reducibility (vide supra). $\mathrm{CeO}_{2}$ demonstrates a linear dehydrochlorination trend with temperature when only EDC is fed, while an increased VCM yield and a shift to lower temperatures is attained when $\mathrm{O}_{2}$ and $\mathrm{HCl}$ are mixed with the 
EDC. Nevertheless, at $773 \mathrm{~K}$ the yield is heavily decreased due to more extensive CO formation, which can be traced back to the higher reducibility of $\mathrm{CeO}_{2}$ (Figs. 5a, 7a, b) that causes the combustion of chlorinated products. EuOCl-p-973 exhibits a linear trend with no $\mathrm{CO}_{x}$ formation and an enhanced selectivity to $\mathrm{VCM}$ when $\mathrm{HCl}+\mathrm{O}_{2}$ is added to the feed.

\subsection{Integration of high activity and selectivity functions}

The fact that the VCM yield over $\mathrm{EuOCl}$ is limited by its low intrinsic oxychlorination activity while the VCM selectivity over $\mathrm{CeO}_{2}$ is compromised by the formation of $\mathrm{CO}_{x}$ and over-chlorinated compounds, encouraged us to consider the possibility of integrating the advantageous qualities of each of these rare-earth compounds in the form of mixed oxides. Consequently, we prepared samples with molar fractions of europium ranging from 0.3-0.9 by coprecipitation (Table 2). The resulting materials were evaluated in ethylene oxychlorination at $673 \mathrm{~K}$ to maximize the activity while minimizing the likelihood of overoxidation (Fig. 8). The yield of chlorinated products (and thus the $\mathrm{C}_{2} \mathrm{H}_{4}$ conversion) is found to reach a maximum over $\mathrm{Eu}_{0.4} \mathrm{Ce}_{0.6} \mathrm{O}_{1.8} \mathrm{cp}-773$. A further increase in cerium contents in these precipitated samples cause a drop in activity and also lead to the formation of overchlorinated products (1,2-DCE).

Analysis by $\mathrm{N}_{2}$ sorption indicated that the total surface area of the mixed oxides was generally lower than the corresponding single phases (Table 2), which gives a first hint of the interaction of $\mathrm{Eu}$ and $\mathrm{Ce}$ in these systems. Due to the similar crystal structures of $\mathrm{Eu}_{2} \mathrm{O}_{3}$ and $\mathrm{CeO}_{2}$, it is difficult to conclude whether the fresh $\mathrm{Eu}_{x} \mathrm{Ce}_{1-x} \mathrm{O}_{2-0.5 x}-\mathrm{cp}-T_{\text {cal }}$ materials are physical mixtures of the single oxides or atomically-dispersed mixed metal oxides (i.e. having metal to metal interactions/bonding within the oxide network) by XRD (Fig. S5). Analysis of the equilibrated samples only evidences the presence of the EuOCl phase in samples with a europium fraction above 0.6. The fact that the oxychloride is not observed for $x \leq 0.5$ corroborates the strong interaction between $\mathrm{Eu}$ and $\mathrm{Ce}$ in the mixed phase. Consistently, the cell parameter of $5.38 \AA$ was derived for $\mathrm{Eu}_{0.4} \mathrm{Ce}_{0.6} \mathrm{O}_{1.8} \mathrm{cp}-773$, the best 
sample in terms of VCM yield, which lies between that of the $\mathrm{CeO}_{2}-\mathrm{p}-773(5.35 \AA)$ and $\mathrm{Eu}_{2} \mathrm{O}_{3}-\mathrm{p}-773(5.41 \AA)$. Examination by electron microscopy (Fig. 3e) shows that the equilibrated sample is composed of small nanoparticles of ca. $5-10 \mathrm{~nm}$, preserving the crystallinity of the as prepared material (not shown for brevity). The elemental map reveals a very homogeneous distribution of europium and cerium atoms, which is also similar to the fresh analogue. Interestingly, the EDX spectrum evidences a small amount of chlorine in the equilibrated sample, which is also corroborated by XPS results showing a shift of the $\mathrm{Eu} 4 d_{3 / 2}$ and Eu $4 d_{5 / 2}$ peaks to higher binding energy compared to the as-prepared sample due to the presence of chlorine (Fig. 4b). Thus, the oxychloride phase could still exist at the surface leading to high acidity. This reasoning is consistent with the highest VCM yield of this sample (Fig. 1). Comparing the performance of $\mathrm{Eu}_{0.4} \mathrm{Ce}_{0.6} \mathrm{O}_{1.8}-\mathrm{cp}-773$ with EuOCI-p-973 and $\mathrm{CeO}_{2}-\mathrm{p}-773$, it is clear that the mixed oxide leads to very selective VCM formation (Fig. 8) and minimal combustion.

Since stability is a crucial driver in the hunt for new catalytic systems to improve the current ethylene oxychlorination process, the long-term performance of EuOCI-p-973 and $\mathrm{Eu}_{0.4} \mathrm{Ce}_{0.6} \mathrm{O}_{1.8}-\mathrm{cp}-773$ was evaluated, demonstrating a stable operation in ethylene oxychlorination for over 100 and $40 \mathrm{~h}$ on stream with VCM yields of $15 \%$ and $19 \%$, respectively (Fig. 9). Even though a minor amount of 1,2-DCE (estimated by carbon mass balance error of about 5-6\%) is observed for $\mathrm{Eu}_{0.4} \mathrm{Ce}_{0.6} \mathrm{O}_{1.8}-\mathrm{cp}-773$ up to $20 \mathrm{~h}$, after which it drops with time-on-stream, the mixed oxide evidences higher activity as it is operated at $50 \mathrm{~K}$ lower temperature and one fourth of the space time $\left(63 \mathrm{~g} \mathrm{~h} \mathrm{~mol}^{-1}\right.$ compared to $252 \mathrm{~g} \mathrm{~h} \mathrm{~mol}^{-1}$ ). To further assess the stability of EuOCl, we conducted a catalytic test doubling the reactant concentration, which resulted in a very similar selectivity pattern $(4 \%$ EDC, $96 \%$ VCM) as observed under standard conditions at comparable $\mathrm{C}_{2} \mathrm{H}_{4}$ conversion (19\%). Besides, no volatilization of the active phase was evidenced, for example by deposits commonly observed on the reactor walls when using unstable materials, under either condition. Still, the VCM yield achieved is not yet optimal (Fig. 8). In fact, although $\mathrm{CeO}_{2}-\mathrm{p}$ - 
773 suffers from $\mathrm{CO}_{x}$ and 1,2-DCE formation, the overall yield of desired EDC and VCM was higher compared to $\mathrm{Eu}_{0.4} \mathrm{Ce}_{0.6} \mathrm{O}_{1.8} \mathrm{cp}-773$.

As an alternative approach to improve the $\mathrm{VCM}$ yield, $\mathrm{CeO}_{2}$ and $\mathrm{EuOCl}$ were united in a dual-bed reactor, combining the high activity of $\mathrm{CeO}_{2}$ in a first bed in the direction of flow in order to enhance the EDC formation with the unique selectivity to VCM of EuOCI due to its acidity in a second bed $\left(\mathrm{CeO}_{2}-\mathrm{p}-\mathrm{EuOCl}-\mathrm{p}-\mathrm{db}\right)$. Advantageously, this could also enable an efficient utilization of the heat generated by the exothermic oxychlorination in the downstream endothermic dehydrochlorination. This system indeed results in the highest VCM (27\%) and VCM+EDC (33\%) yields observed so far at the standard space time of $63 \mathrm{~g} \mathrm{~h} \mathrm{~mol}^{-1}$ applied in this study. Even though small amounts of side products $\left(\mathrm{CO}_{2}\right.$ and 1,2-DCE) are formed in the first bed by $\mathrm{CeO}_{2}$ (Fig. 8), this dual-bed system shows the highest rate of VCM production per unit surface area of the catalyst (Table 2). Since both, $\mathrm{EuOCI}$ (Fig. 9) and $\mathrm{CeO}_{2}$ [13] are individually stable, a highly robust operation of this dualbed reactor can be anticipated.

\section{Conclusions}

In this study, we developed a fundamental understanding of the ethylene oxychlorination chemistry on scarcely studied rare-earth compounds. Through the integration of steady-state catalytic tests and advanced characterization, we identified $\mathrm{EuOCl}$ as the best catalyst for direct VCM production, leading to $96 \%$ selectivity and no $\mathrm{CO}_{x}$ formation at $20 \%$ ethylene conversion for over $100 \mathrm{~h}$ on stream. The consecutive conversion of ethylene to EDC and EDC to VCM confirmed the bifunctional reaction mechanism over this catalyst. This unique behavior was found to originate from the transformation of the initial $\mathrm{Eu}_{2} \mathrm{O}_{3}$ phase to a stable oxychloride. The latter was completely inert towards ethylene and CO oxidation, which explains the absence of undesired $\mathrm{CO}_{x}$, while it exhibited moderate $\mathrm{HCl}$ oxidation, demonstrating its ability to chlorinate ethylene. Other lanthanide oxides, except $\mathrm{CeO}_{2}$ which retained the oxide structure after reaction, also transformed to their respective oxychloride or 
chloride phases. However, these oxychlorides were either essentially inactive in ethylene oxychlorination or decomposed in oxidative conditions and catalyzed undesired oxidations forming significant amounts of $\mathrm{CO}_{x}$, as demonstrated for the case of PrOCl. Another crucial aspect of the EuOCl phase was the presence of a high concentration of acid sites, which catalyzed the EDC dehydrochlorination to produce VCM. By combining $\mathrm{CeO}_{2}$ for its high activity towards $\mathrm{EDC}$ with $\mathrm{Eu}_{2} \mathrm{O}_{3}$ or $\mathrm{EuOCl}$ for $\mathrm{VCM}$, in the form of homogeneously mixed oxides or as a dual-bed system, respectively, we demonstrated industrially attractive VCM yields (ca. 30\%). The intensification feasibility studied herein can be anticipated to be more economical than the current two-step process as it enables reduction of the unit operations eliminating the need for the intermediate EDC purification and subsequent cracking steps.

Acknowledgements. This work was sponsored by Swiss National Science Foundation (project no. 200021-156107). The authors acknowledge Dr. R. Hauert (Empa, Switzerland) for XPS analysis.

\section{References}

[1] Renolit, Everything about PVC, 2015, http://www.renolit.com/fileadmin/renolit/corporate/images/Everything_about_PVC.pdf (accessed July 22, 2016).

[2] Plastics Today, Global PVC demand to grow 3.2\% annually through 2021, 2014, http://www.plasticstoday.com/study-global-pvc-demand-grow-32-annually-through2021/196257501821043 (accessed July 22, 2016).

[3] K. Weissermel, H.-J. Arpe, in: Industrial Organic Chemistry, Wiley-VCH, Weinheim, 2008, pp. 217-224.

[4] E.-L. Dreher, K.K. Beutel, J.D. Myers, T. Lübbe, S. Krieger, L.H. Pottenger, in: Ullmann's Encyclopedia of Industrial Chemistry, Wiley-VCH, Weinheim, 2000, pp. 9-17. 
[5] J.S. Naworski, E.S. Velez, in: Applied Industrial Catalysis, Academic Press, New York, 1983, p. 239.

[6] N.B. Muddada, U. Olsbye, L. Caccialupi, F. Cavani, G. Leofanti, D. Gianolio, S. Bordiga, C. Lamberti, Influence of additives in defining the active phase of the ethylene oxychlorination catalyst, Phys. Chem. Chem. Phys. 12 (2010) 5605-5618.

[7] N.B. Muddada, T. Fuglerud, C. Lamberti, U. Olsbye, Tuning the activity and selectivity of $\mathrm{CuCl}_{2} / \gamma-\mathrm{Al}_{2} \mathrm{O}_{3}$ ethene oxychlorination catalyst by selective promotion, Top. Catal. 57 (2014) 741-756.

[8] F.E. Van Rooijen, A. De Bruijn, J. Johan, Catalytic Oxychlorination, US Patent US2009/0054708 A1 (2009), to Albemarle Netherlands B.V.

[9] M. Malentacchi, C. Rubini, Oxychlorination catalytic composition for controlling exothermic reactions in a fixed bed, European Patent 1020222 B1 (2004), to Süd Chemie Mt S.R.L.

[10] I.M. Clegg, R. Hardman, Vinyl chloride production process, US Patent 5728905 (1998), to EVC Technologies AG.

[11] L.J. Croce, L. Bajars, M. Gabliks, Oxychlorination of hydrocarbons in the presence of non-halide copper containing catalysts, US Patent 4025461 (1977), to Petro-Tex Chemical Corporation.

[12] M.E. Jones, M.M. Olken, D.A. Hickman, Process for the conversion of ethylene to vinyl chloride and novel catalyst compositions useful for such process, US Patent 6909024 B1 (2005), to The Dow Chemical Company.

[13] M. Scharfe, P.A. Lira-Parada, V. Paunović, M. Moser, A.P. Amrute, J. Pérez-Ramírez, Oxychlorination-dehydrochlorination chemistry on bifunctional ceria catalysts for intensified vinyl chloride production, Angew. Chem. Int. Ed. 55 (2016) 3068-3072.

[14] M.A. Centeno, P. Malet, I. Carrizosa, J.A. Odriozola, Lanthanide doped $\mathrm{V}_{2} \mathrm{O}_{5} / \mathrm{Al}_{2} \mathrm{O}_{3}$ catalysts: Structure-activity relationship in the SCR of $\mathrm{NO}_{x}$, J. Phys. Chem. B 104 (2000) 3310-3319. 
[15] W.Y. Hernández, F. Romero-Sarria, M.A. Centeno, J.A. Odriozola, In situ characterization of the dynamic gold-support interaction over ceria modified $\mathrm{Eu}^{3+}$. Influence of the oxygen vacancies on the CO oxidation reaction, J. Phys. Chem. C 114 (2010) 10857-10865.

[16] T. Montini, M. Melchionna, M. Monai, P. Fornasiero, Fundamentals and catalytic applications of $\mathrm{CeO}_{2}$-based materials, Chem. Rev. 116 (2016) 5987-6041.

[17] M. Cargnello, N.L. Wieder, T. Montini, R.J. Gorte, P. Fornasiero, Synthesis of dispersible Pd@ $\mathrm{CeO}_{2}$ core-shell nanostructures by self-assembly, J. Am. Chem. Soc. 132 (2010) 1402-1409.

[18] K. Tamm, R. Küngas, R.J. Gorte, E. Lust, Solid oxide fuel cell anodes prepared by infiltration of strontium doped lanthanum vanadate into doped ceria electrolyte, Electrochim. Act. 106 (2013) 398-405.

[19] J. Kašpar, P. Fornasiero, M. Graziani, Use of $\mathrm{CeO}_{2}$-based oxides in the three-way catalysis, Catal. Today 50 (1999) 285-298.

[20] D. Valechha, S. Lokhande, M. Klementova, J. Subrt, S. Rayalu, N.L. Labhsetwar, Study of nano-structured ceria for catalytic CO oxidation, Mater. Chem. 21 (2011) 3718-3725.

[21] C. de Leitenburg, A. Trovarelli, J. Llorca, F. Cavani, G. Bini, The effect of doping $\mathrm{CeO}_{2}$ with zirconium in the oxidation of isobutene, Appl. Catal. A 139 (1996) 161-173.

[22] A.P. Amrute, C. Mondelli, M. Moser, G. Novell-Leruth, N. López, D. Rosenthal, R. Farra, M.E. Schuster, D. Teschner, T. Schmidt, J. Pérez-Ramírez, Performance, structure, and mechanism of $\mathrm{CeO}_{2}$ in $\mathrm{HCl}$ oxidation to $\mathrm{Cl}_{2}$, J. Catal. 286 (2012) 287-297.

[23] M. Moser, A.P. Amrute, J. Pérez-Ramírez, Impact of feed impurities on catalysts for chlorine recycling, Appl. Catal. B 162 (2015) 602-609.

[24] J.H. Lunsford, The catalytic oxidative coupling of methane, Angew. Chem. Int. Ed. 34 (1995) 970-980.

[25] T.J. Toops, A.B. Walters, M.A. Vannice, The effect of $\mathrm{CO}_{2}$ and $\mathrm{H}_{2} \mathrm{O}$ on the kinetics of NO reduction by $\mathrm{CH}_{4}$ over a $\mathrm{La}_{2} \mathrm{O}_{3} / \gamma-\mathrm{Al}_{2} \mathrm{O}_{3}$ catalyst, J. Catal. 214 (2003) 292-307. 
[26] S.G. Podkolzin, E.E. Stangland, M.E. Jones, E. Peringer, J.A. Lercher, Methyl chloride production from methane over lanthanum-based catalysts, J. Am. Chem. Soc. 129 (2007) 2569-2576.

[27] J. He, T. Xu, Z. Wang, Q. Zhang, W. Deng, Y. Wang, Transformation of methane to propylene: A two-step reaction route catalyzed by modified $\mathrm{CeO}_{2}$ nanocrystals and zeolites, Angew. Chem. Int. Ed. 51 (2012) 2438-2442.

[28] S. Brunauer, P.H. Emmett, E. Teller, Adsorption of gases in multimolecular layers, J. Am. Chem. Soc. 60 (1938) 309-319.

[29] F. Mercier, C. Alliot, L. Bion, N. Thromat, P. Toulhoat, XPS study of Eu(III) coordination compounds: Core levels binding energies in solid mixed-oxo-compounds $\mathrm{Eu}_{m} \mathrm{X}_{x} \mathrm{O}_{y}, \mathrm{~J}$. Electron. Spectros. Relat: Phenomena 150 (2006) 21-26.

[30] S. Kumar, R. Prakash, R.J. Choudhary, D.M. Phase, Structural, XPS and magnetic studies of pulsed laser deposited Fe doped $\mathrm{Eu}_{2} \mathrm{O}_{3}$ thin film, Mater. Res. Bull. 70 (2015) 392-396.

[31] Y. Uwamino, A. Tsuge, T. Ishizuka, H. Yamatera, X-Ray photoelectron spectroscopy of rare earth halides, Bull. Chem. Soc. Jpn. 59 (1986) 2263-2267.

[32] A.S. Shalygin, L.V. Malysheva, E.A. Paukshtis, Mechanism of 1,2-dichloroethane dehydrochlorination on the acid sites of oxide catalysts as studied by IR spectroscopy, Kinet. Catal. 52 (2011) 305-315.

[33] H.C. Yao, Y.F. Yu Yao, Ceria in automotive exhaust catalysts: I. Oxygen storage, J. Catal. 86 (1984) 254-265.

[34] A. Trovarelli, Catalytic properties of ceria and $\mathrm{CeO}_{2}$-containing materials, Catal. Rev. Sci. Eng. 38 (1996) 439-518.

[35] R. Farra, S. Wrabetz, M.E. Schuster, E. Stotz, N.G. Hamilton, A.P. Amrute, J. PérezRamírez, N. López, D. Teschner, Understanding $\mathrm{CeO}_{2}$ as a deacon catalyst by probe molecule adsorption and in situ infrared characterizations, Phys. Chem. Chem. Phys. 15 (2013) 3454-3465. 
Table 1. Total surface area of the samples prior to (fresh) and after (equilibrated) ethylene oxychlorination. The nomenclature of the used samples reflects the main crystallographic phase identified in the catalyst.

\begin{tabular}{lclc}
\hline Fresh sample $^{\mathbf{a}}$ & $\mathbf{S}_{\mathrm{BET}}{ }^{\mathbf{b}}\left(\mathbf{m}^{\mathbf{2}} \mathbf{g}^{-\mathbf{1}}\right)$ & Equilibrated sample & $\mathbf{S}_{\mathrm{BET}}{ }^{\mathbf{b}}\left(\mathbf{m}^{\mathbf{2}} \mathbf{g}^{-\mathbf{1}}\right)$ \\
\hline $\mathrm{La}_{2} \mathrm{O}_{3}$ & 6 & $\mathrm{LaCl}_{3}$ & 8 \\
$\mathrm{CeO}_{2}$ & 45 & $\mathrm{CeO}_{2}$ & 28 \\
$\mathrm{Pr}_{4} \mathrm{O}_{7}$ & 5 & $\mathrm{PrOCl}$ & 6 \\
$\mathrm{Nd}_{2} \mathrm{O}_{3}$ & 32 & $\mathrm{NdCl}$ & \\
$\mathrm{Sm}_{2} \mathrm{O}_{3}$ & 10 & $\mathrm{SmOCl}$ & 21 \\
$\mathrm{Eu}_{2} \mathrm{O}_{3}$ & 11 & $\mathrm{EuOCl}$ & 8 \\
$\mathrm{Eu}_{2} \mathrm{O}_{3}-\mathrm{p}-773$ & 37 & $\mathrm{EuOCl}-\mathrm{p}-773$ & 8 \\
$\mathrm{Eu}_{2} \mathrm{O}_{3}-\mathrm{p}-973$ & 31 & $\mathrm{EuOCl}-\mathrm{p}-973$ & 26 \\
$\mathrm{Eu}_{2} \mathrm{O}_{3}-\mathrm{p}-1173$ & 14 & $\mathrm{EuOCl}-\mathrm{p}-1173$ & 23 \\
$\mathrm{Gd}_{2} \mathrm{O}_{3}$ & 5 & $\mathrm{GdOCl}$ & 12 \\
$\mathrm{~Tb}_{2} \mathrm{O}_{3}$ & 4 & $\mathrm{TbOCl}$ & 16 \\
$\mathrm{Dy}_{2} \mathrm{O}_{3}$ & 29 & $\mathrm{DyOCl}$ & 7 \\
$\mathrm{Ho}_{2} \mathrm{O}_{3}$ & 7 & $\mathrm{HoOCl}$ & 25 \\
$\mathrm{Er}_{2} \mathrm{O}_{3}$ & 60 & $\mathrm{ErCl}$ & 6 \\
\hline $\mathrm{Al}_{3}$ & & & 15 \\
\hline
\end{tabular}

${ }^{a}$ All samples were commercial, except $\mathrm{Eu}_{2} \mathrm{O}_{3}-\mathrm{p}-T_{\text {cal }}$, which was obtained by precipitation and calcination at $T_{\text {cal }} \mathrm{K} .{ }^{\mathrm{b}}$ BET method. 
Table 2. Characterization data and rate of VCM formation of the mixed europium-cerium oxides.

\begin{tabular}{lccc}
\hline Sample & $\mathrm{Eu}_{\mathrm{C}} \mathrm{Ce}^{\mathrm{a}}\left(\mathbf{m o l ~ m o l}^{-1}\right)$ & $\boldsymbol{S}_{\mathrm{BET}}^{\mathrm{b}}\left(\mathbf{m}^{\mathbf{2}} \mathbf{g}^{-\mathbf{1}}\right)$ & $\boldsymbol{r}(\mathbf{V C M})^{\mathrm{c}}\left(\mathbf{m o l ~ h}^{-1} \mathbf{~ m}^{-2}\right)$ \\
\hline $\mathrm{Eu}_{2} \mathrm{O}_{3}-\mathrm{p}-973$ & $1: 0$ & 31 & $8.96 \times 10^{-6}$ \\
$\mathrm{Eu}_{0.9} \mathrm{Ce}_{0.1} \mathrm{O}_{1.55}-\mathrm{cp}-773$ & $0.9: 0.1$ & 16 & $9.25 \times 10^{-6}$ \\
$\mathrm{Eu}_{0.5} \mathrm{Ce}_{0.5} \mathrm{O}_{1.75} \mathrm{cp}-773$ & $0.51: 0.49$ & 13 & $2.24 \times 10^{-5}$ \\
$\mathrm{Eu}_{0.4} \mathrm{Ce}_{0.6} \mathrm{O}_{1.8}-\mathrm{cp}-773$ & $0.39: 0.61$ & 27 & $2.36 \times 10^{-5}$ \\
$\mathrm{Eu}_{0.3} \mathrm{Ce}_{0.7} \mathrm{O}_{1.85} \mathrm{cp}-773$ & $0.3: 0.7$ & 25 & $1.07 \times 10^{-5}$ \\
$\mathrm{CeO}_{2}-\mathrm{p}-773$ & $0: 1$ & 44 & $1.41 \times 10^{-5}$ \\
$\mathrm{CeO}_{2}-\mathrm{p}-\mathrm{EuOCl}-\mathrm{p}-\mathrm{db}$ & $0.4: 0.6^{\mathrm{d}}$ & $39^{\mathrm{d}}$ & $2.49 \times 10^{-5}$ \\
\hline
\end{tabular}

${ }^{a}$ XRF. ${ }^{b}$ BET method. ${ }^{c}$ Corresponds to data in Fig. 8. ${ }^{d}$ Estimated. 


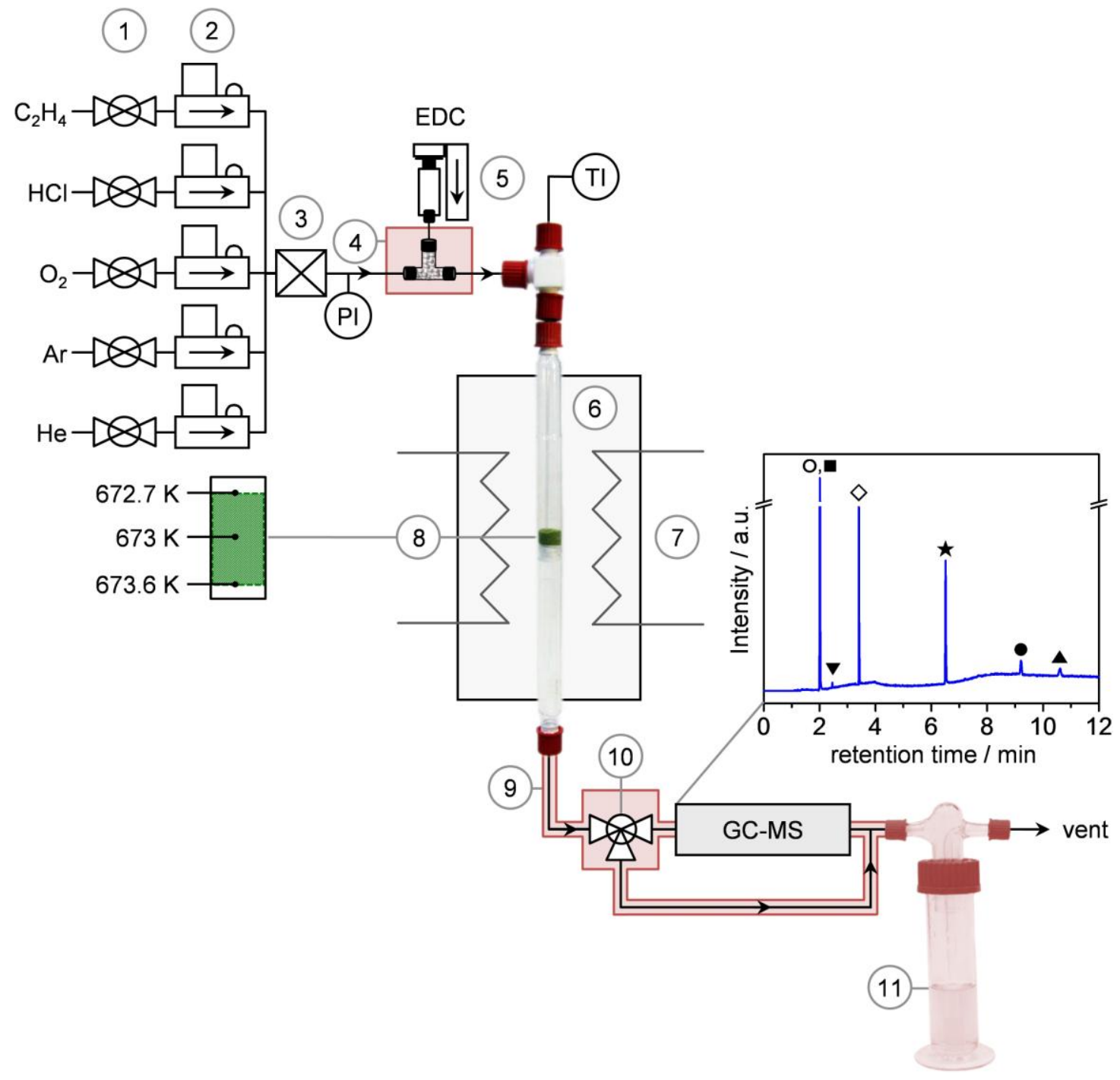

Scheme 1. Scheme of the laboratory set-up used for the catalytic studies. 1: on-off valves, 2: mass flow controllers, 3: mixer, 4: vaporizer, 5: syringe pump, 6: quartz reactor, 7: oven, 8: catalyst bed, 9: heat tracing, 10: three-way bypass valve, 11: $\mathrm{NaOH}$ scrubber, $\mathrm{PI}$ : pressure indicator, and $\mathrm{TI}$ : temperature indicator. The three positions at which the temperature was measured in the catalyst bed are indicated on the left, lying within $\pm 1 \mathrm{~K}$ (measured in a reference experiment over $\mathrm{CeO}_{2}-1173$ at $31 \% \mathrm{C}_{2} \mathrm{H}_{4}$ conversion). The inset on the right depicts a representative chromatogram where the peaks are assigned to the following compounds: $\bigcirc, \mathrm{Ar}$ and $\mathrm{CO}$ (due to the overlapping retention time, these peaks were subsequently separated by mass spectrometry), $\diamond \mathrm{C}_{2} \mathrm{H}_{4}, \nabla \mathrm{CO}_{2}$, vinyl chloride, - 1,2-cis-dichloroethene, and $\boldsymbol{\Delta}$ ethylene dichloride. 


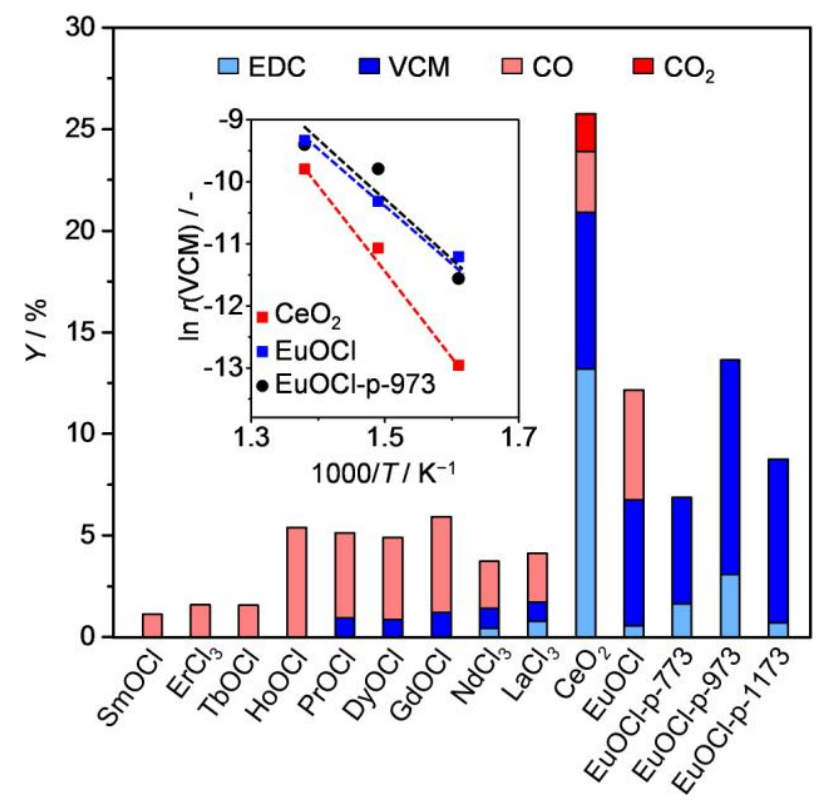

Fig. 1. Product yields $(Y$ ) in ethylene oxychlorination over single metal lanthanide catalysts. The inset depicts the Arrhenius plot of VCM formation over $\mathrm{CeO}_{2}, \mathrm{EuOCl}$, and EuOCI-p-973. Conditions: $T=723 \mathrm{~K}, \mathrm{C}_{2} \mathrm{H}_{4}: \mathrm{HCl}: \mathrm{O}_{2}: \mathrm{Ar}: \mathrm{He}=3: 4.8: 3: 3: 86.2, W_{\text {cat }} / \dot{n}^{0}\left(\mathrm{C}_{2} \mathrm{H}_{4}\right)=63 \mathrm{~g} \mathrm{~h} \mathrm{~mol}^{-1}$. 


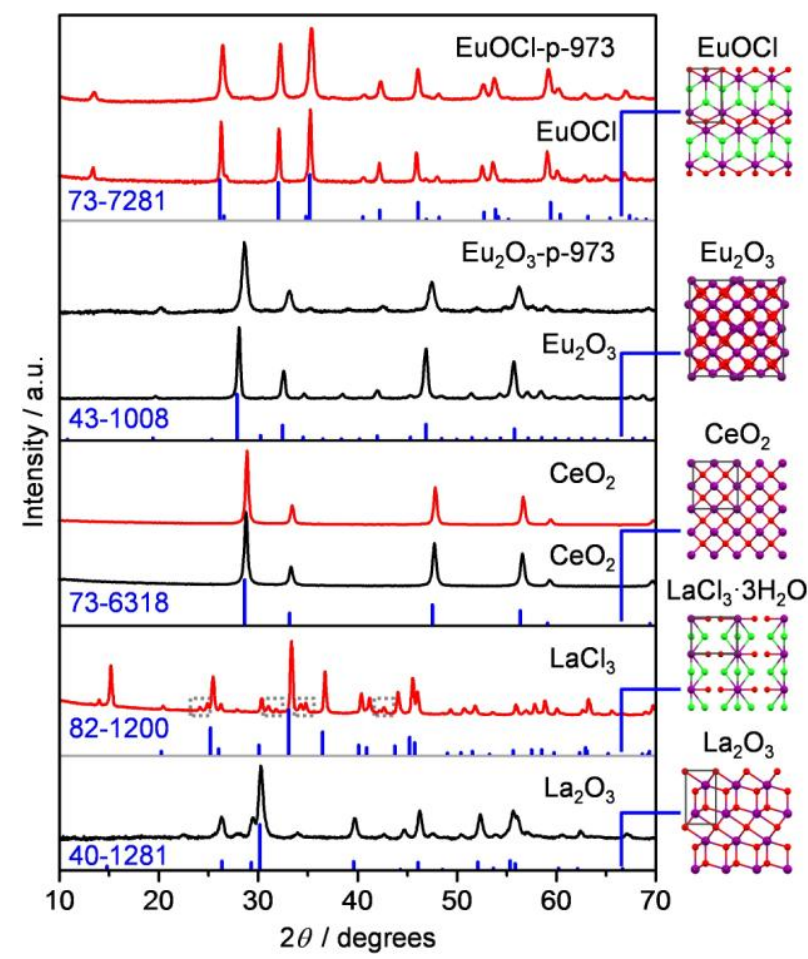

Fig. 2. XRD patterns of selected catalysts prior to (black) and after (red) ethylene oxychlorination. Vertical lines beneath the diffractograms and structures on the right denote identified crystalline phases according to the ICDD PDF numbers provided on the left of the figure. The gray rectangles in the structures represent the corresponding unit cells. Dashed boxes in the diffractogram of $\mathrm{LaCl}_{3}$ highlight the reflections for $\mathrm{LaOCl} \cdot \mathrm{H}_{2} \mathrm{O}$ (ICDD PDF 702139). XRD analysis of all other investigated lanthanide-based catalysts is depicted in Fig. S2. 

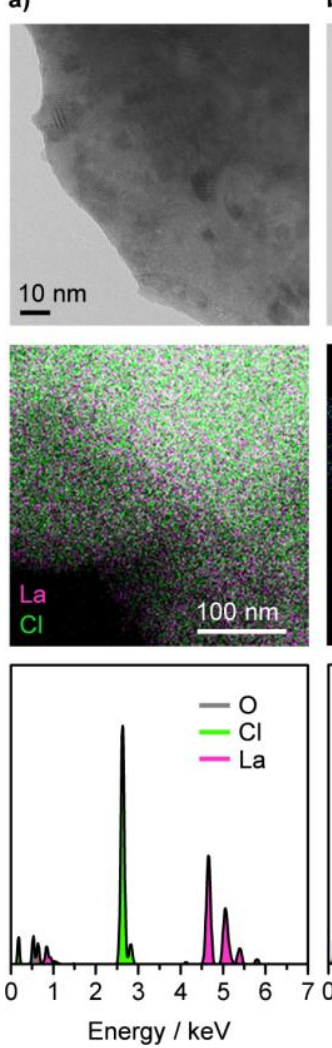

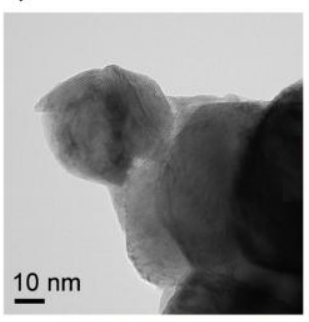

c)
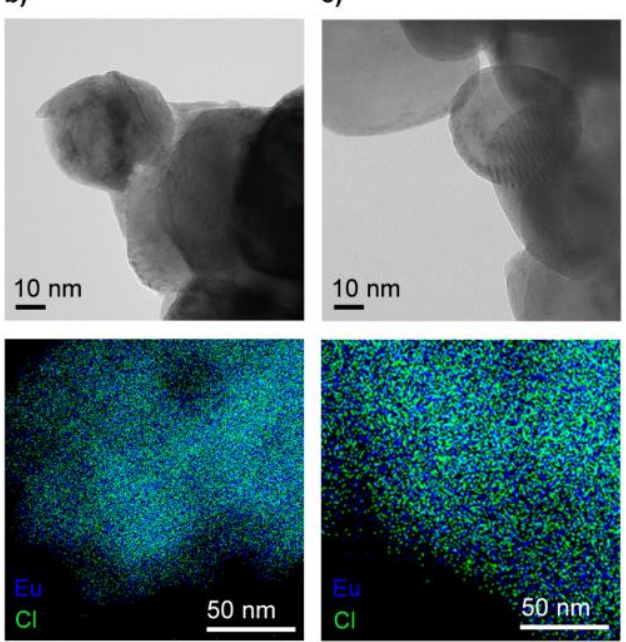

$50 \mathrm{~nm}$

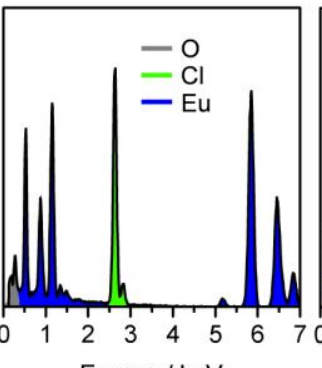

Energy / keV d)
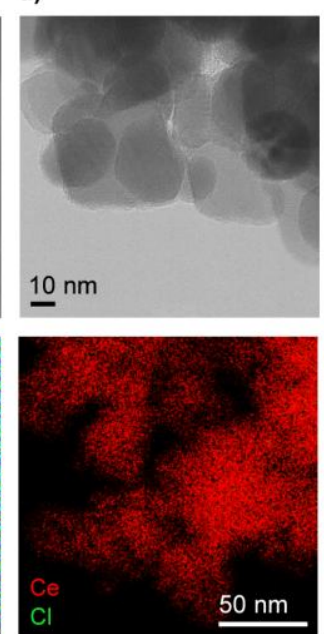

$50 \mathrm{~nm}$

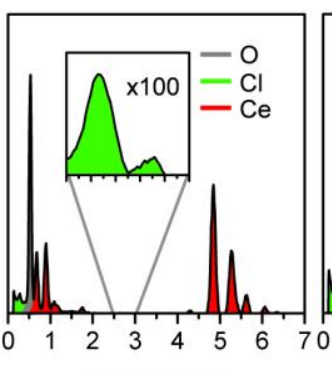

Energy / keV e)
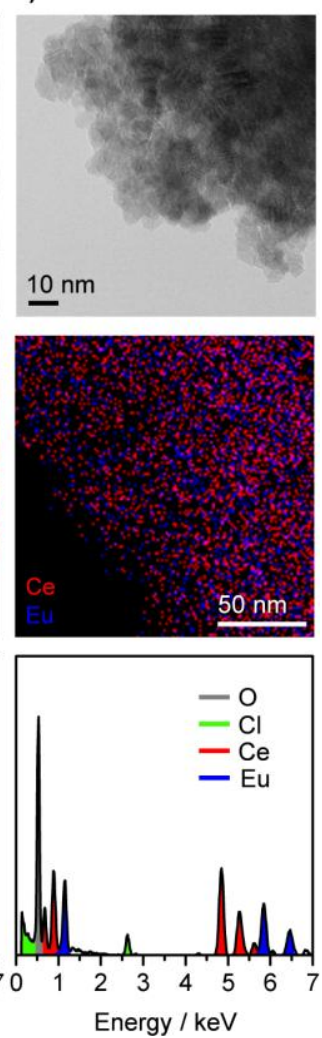

Fig. 3. HRTEM images (top), elemental maps (middle), and corresponding EDX spectra (bottom) of equilibrated catalysts: column a) $\mathrm{LaOCl}$, column b) EuOCl, column c) EuOCl-p973, column d) $\mathrm{CeO}_{2}$, and column e) $\mathrm{Eu}_{0.4} \mathrm{Ce}_{0.6} \mathrm{O}_{1.8}-\mathrm{cp}-773$. 


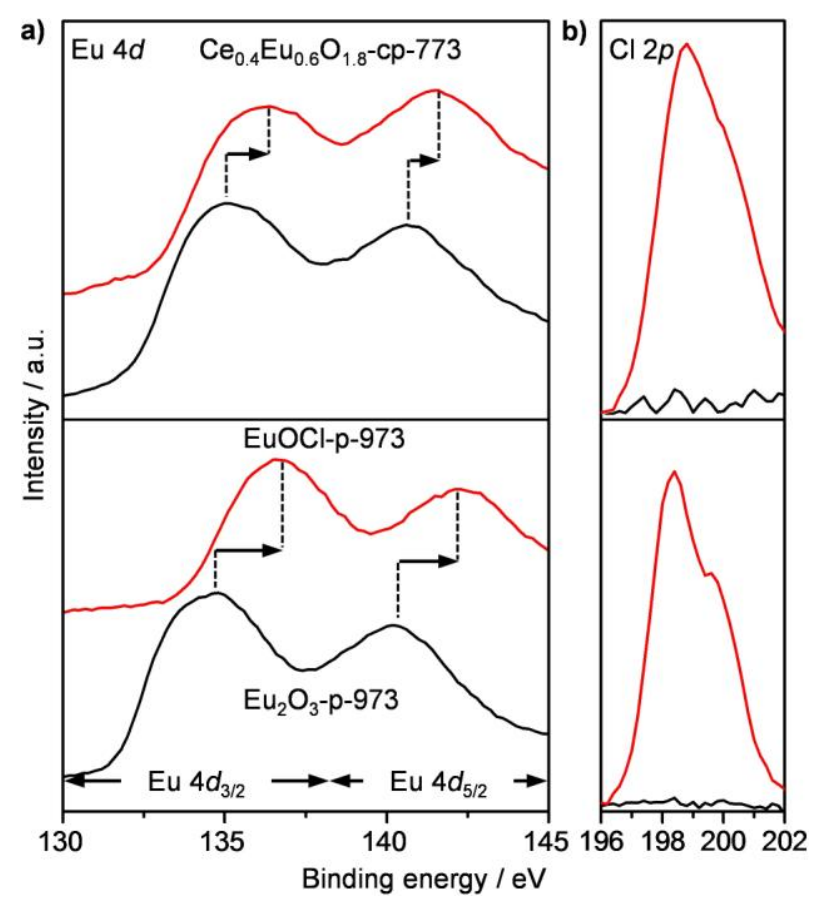

Fig. 4. a) Eu $4 d$ and b) $\mathrm{Cl} 2 p$ core level XPS spectra of fresh (black) and equilibrated (red) europium-based catalysts. 

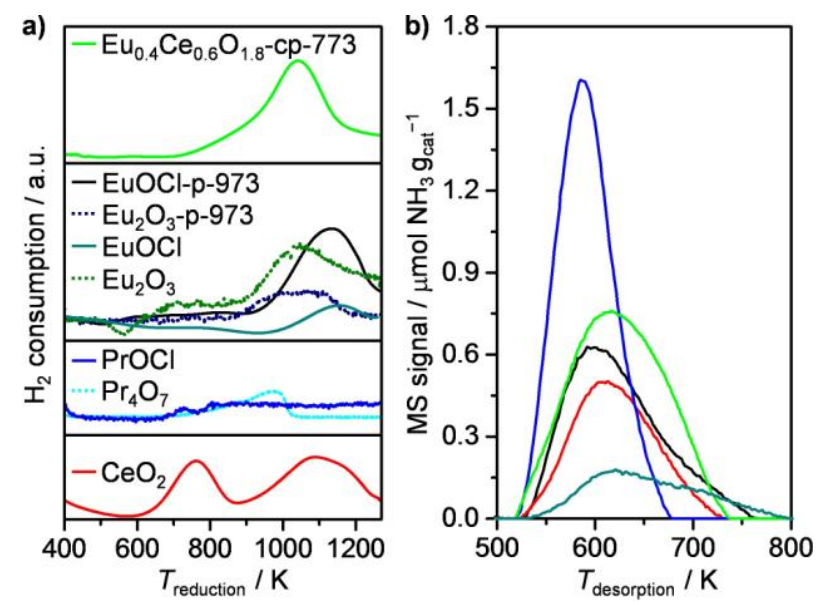

Fig. 5. a) $\mathrm{H}_{2}$-TPR and b) $\mathrm{NH}_{3}$-TPD profiles of selected fresh (dashed lines) and equilibrated (solid lines) catalysts. 

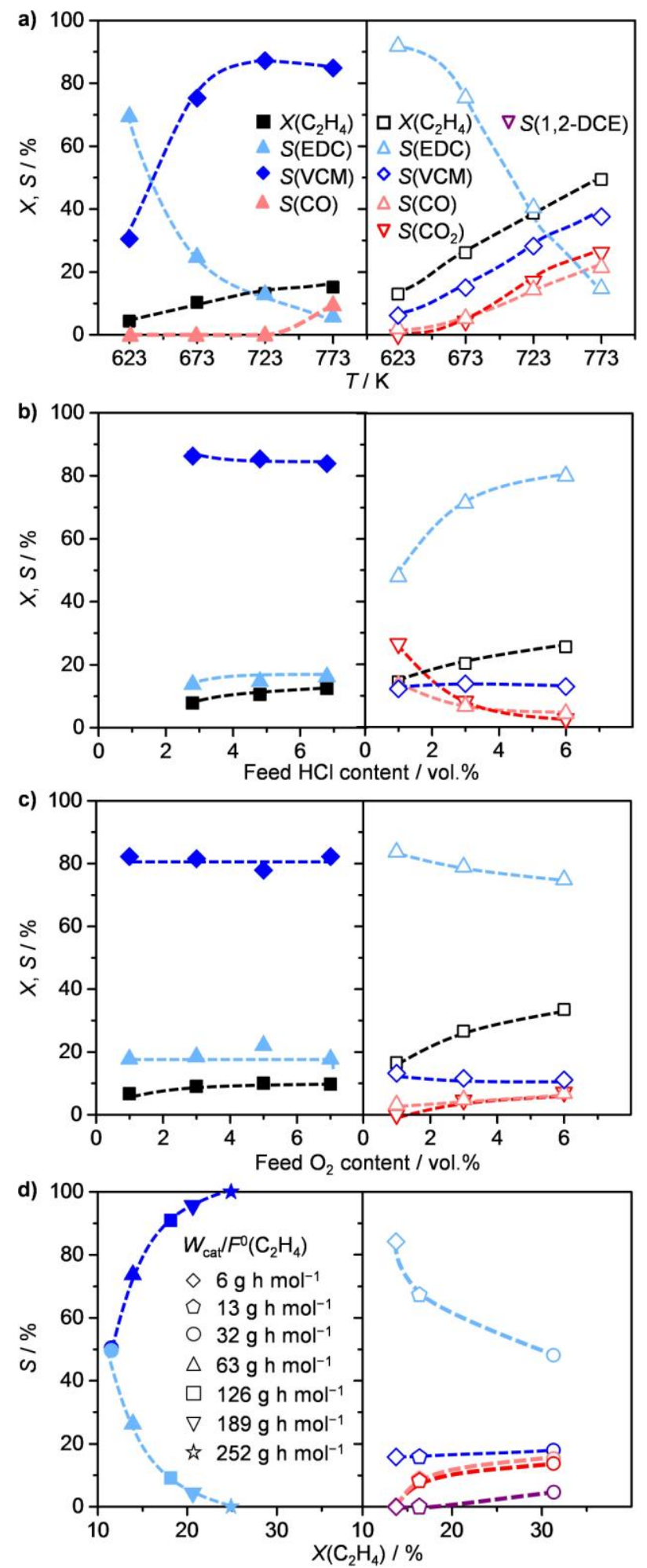

Fig. 6. $\mathrm{C}_{2} \mathrm{H}_{4}$ conversion and product selectivity over EuOCl-p-973 (left) and $\mathrm{CeO}_{2}-1173$ (right) as a function of a) $T$ at fixed $\mathrm{HCl}\left(4.8\right.$ vol.\%) and $\mathrm{O}_{2}$ (3 vol.\%) concentrations, b) feed $\mathrm{HCl}$ content at fixed $\mathrm{O}_{2}$ content $(3 \mathrm{vol} . \%)$ at $723 \mathrm{~K}(\mathrm{EuOCl})$ and $673 \mathrm{~K}\left(\mathrm{CeO}_{2}\right)$, and c) feed $\mathrm{O}_{2}$ content at fixed $\mathrm{HCl}$ content $(4.8 \mathrm{vol} . \%)$ at $723 \mathrm{~K}(\mathrm{EuOCl})$ and $673 \mathrm{~K}\left(\mathrm{CeO}_{2}\right)$. d) Selectivity to 
products versus conversion at different space times at $723 \mathrm{~K}$ at fixed $\mathrm{HCl}\left(4.8\right.$ vol.\%) and $\mathrm{O}_{2}$ (3 vol.\%) concentrations, color code as in a-c. Conditions: a-c) $W_{\text {cat }} / \dot{n}^{0}\left(\mathrm{C}_{2} \mathrm{H}_{4}\right)=63 \mathrm{~g} \mathrm{~h} \mathrm{~mol}{ }^{-1}$, d) $W_{\text {cat }} / \dot{n}^{0}\left(\mathrm{C}_{2} \mathrm{H}_{4}\right)=6-252 \mathrm{~g} \mathrm{~h} \mathrm{~mol}^{-1}$. 

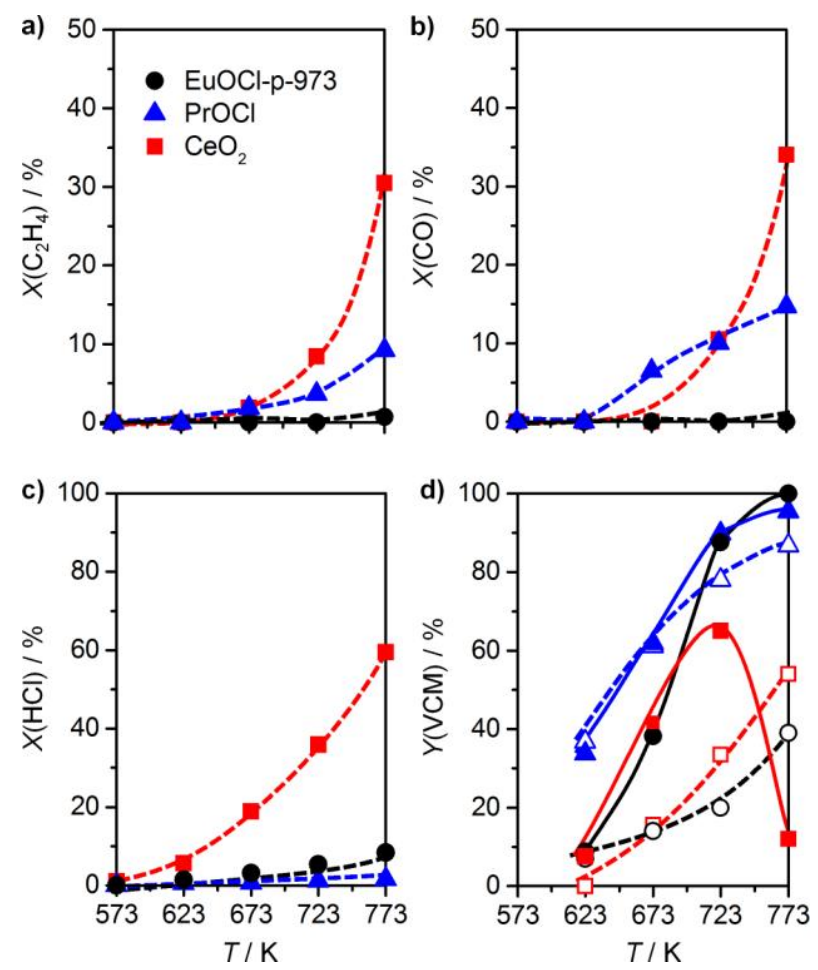

Fig. 7. Performance descriptors for selective VCM production over equilibrated catalysts. a) $\mathrm{C}_{2} \mathrm{H}_{4}$ oxidation to $\mathrm{CO}_{2}\left(\mathrm{C}_{2} \mathrm{H}_{4}: \mathrm{O}_{2}: \mathrm{Ar}: \mathrm{He}=3: 3: 3: 91, W_{\text {cat }} / \dot{n}^{0}\left(\mathrm{C}_{2} \mathrm{H}_{4}\right)=63 \mathrm{~g} \mathrm{~h} \mathrm{~mol}^{-1}\right)$, b) $\mathrm{CO}$ oxidation to $\left.\mathrm{CO}_{2}\left(\mathrm{CO}: \mathrm{O}_{2}: \mathrm{Ar}: \mathrm{He}=2.5: 2.5: 3: 92, W_{\text {cat }} / \tilde{n}^{0}(\mathrm{CO})=76 \mathrm{~g} \mathrm{~h} \mathrm{~mol}^{-1}\right), \mathbf{c}\right) \mathrm{HCl}$ oxidation to $\mathrm{Cl}_{2} \quad\left(\mathrm{HCl}: \mathrm{O}_{2}: \mathrm{Ar}: \mathrm{He}=3: 3: 3: 91, \quad W_{\text {cat }} / \dot{n}^{0}(\mathrm{HCl})=63 \mathrm{~g} \mathrm{~h} \mathrm{~mol}^{-1}\right), \quad$ and $\quad$ d) $\quad \mathrm{EDC}$ dehydrochlorination to VCM. In d) $W_{\text {cat }} / \dot{n}^{0}(\mathrm{EDC})=126 \mathrm{~g} \mathrm{~h} \mathrm{~mol}^{-1}$, open symbols: EDC: Ar: $\mathrm{He}=1.5: 3: 95.5$, and solid symbols: $\mathrm{EDC}: \mathrm{HCl}_{2}: \mathrm{Ar}: \mathrm{He}=1.5: 4.8: 3: 3: 87.7$. 


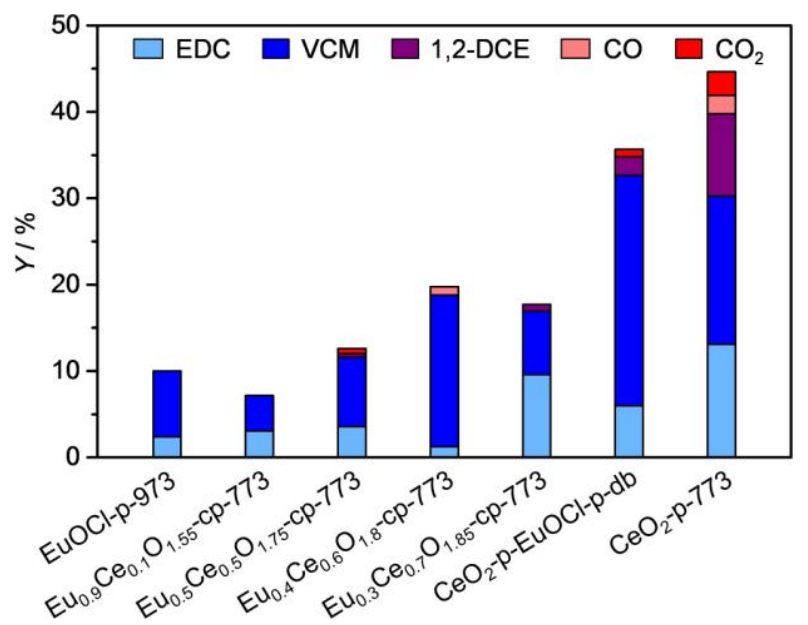

Fig. 8. Product yields in ethylene oxychlorination over EuOCl-p-973, $\mathrm{CeO}_{2}-\mathrm{p}-773$, mixed oxides of $\mathrm{Eu}$ and $\mathrm{Ce}$, and the dual-bed configuration of $\mathrm{CeO}_{2}-\mathrm{p}-773$ and EuOCl-p-973. Conditions: $T=673 \mathrm{~K}, \mathrm{C}_{2} \mathrm{H}_{4}: \mathrm{HCl}: \mathrm{O}_{2}: \mathrm{Ar}: \mathrm{He}=3: 4.8: 3: 3: 86.2, W_{\text {cat }} / \dot{n}^{0}\left(\mathrm{C}_{2} \mathrm{H}_{4}\right)=63 \mathrm{~g} \mathrm{~h} \mathrm{~mol}^{-1}$. 

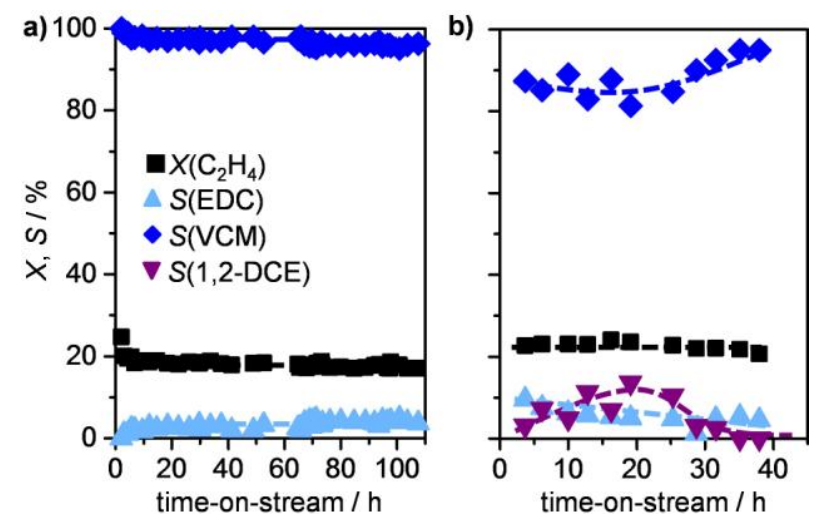

Fig. 9. $\mathrm{C}_{2} \mathrm{H}_{4}$ conversion and product selectivities versus time-on-stream in ethylene oxychlorination over a) EuOCl-p-973 and b) $\mathrm{Eu}_{0.4} \mathrm{Ce}_{0.6} \mathrm{O}_{1.8}-\mathrm{cp}-773$. Conditions: $T=723 \mathrm{~K}$ (673 K for $\left.\mathrm{Eu}_{0.4} \mathrm{Ce}_{0.6} \mathrm{O}_{1.8}-\mathrm{cp}-773\right), \mathrm{C}_{2} \mathrm{H}_{4}: \mathrm{HCl}: \mathrm{O}_{2}: \mathrm{Ar}: \mathrm{He}=3: 4.8: 1.5: 3: 87.7\left(\mathrm{C}_{2} \mathrm{H}_{4}: \mathrm{HCl}_{2}: \mathrm{O}_{2}: \mathrm{Ar}: \mathrm{He}\right.$ = 3:4.8:3:3:86.2 for $\left.\mathrm{Eu}_{0.4} \mathrm{Ce}_{0.6} \mathrm{O}_{1.8}-\mathrm{cp}-773\right), W_{\text {cat }} / \dot{n}^{0}\left(\mathrm{C}_{2} \mathrm{H}_{4}\right)=252 \mathrm{~g} \mathrm{~h} \mathrm{~mol}^{-1}\left(63 \mathrm{~g} \mathrm{~h} \mathrm{~mol}^{-1}\right.$ for $\left.\mathrm{Eu}_{0.4} \mathrm{Ce}_{0.6} \mathrm{O}_{1.8}-\mathrm{cp}-773\right)$ 


\section{Graphical abstract}

Lanthanide compounds as catalysts for the one-step synthesis of vinyl chloride from ethylene

M. Scharfe, P.A. Lira-Parada, A.P. Amrute, S. Mitchell, and J. Pérez-Ramírez

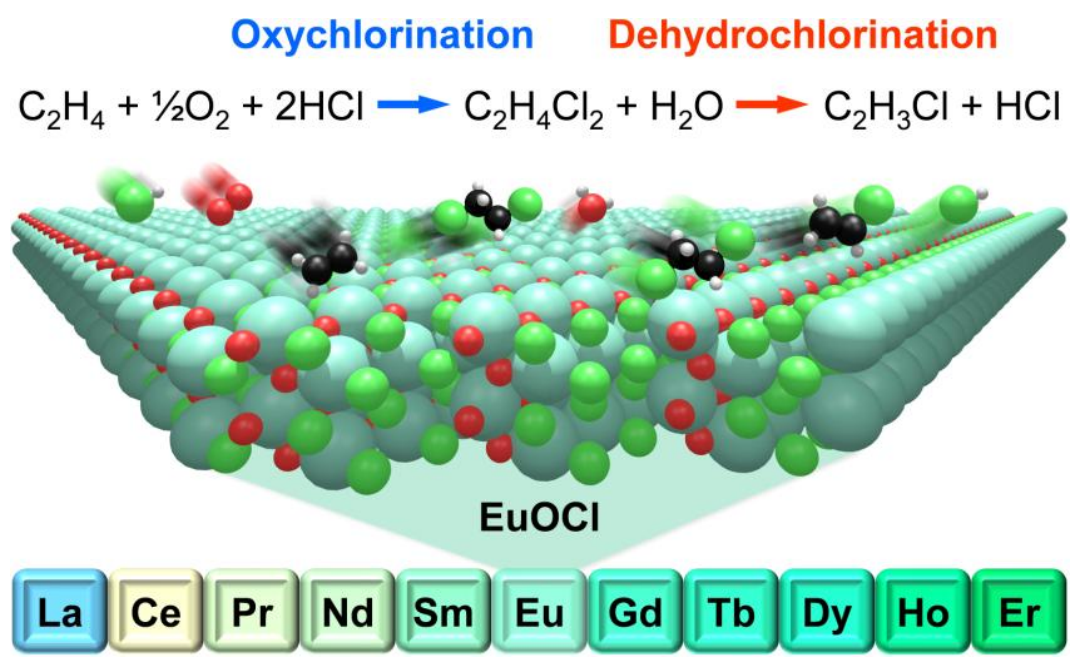

